\title{
WHY MARKETS CRASH AND WHAT LAW CAN DO ABOUT IT
}

\author{
Frank Partnoy*
}

\section{INTRODUCTION}

Markets crash. ${ }^{1}$ And when they do, they cause pain. ${ }^{2}$ These two facts are well known to both investors and scholars.

Yet after hundreds of market crashes, ${ }^{3}$ and centuries of study, we understand very little about them. Economists continue to debate why

* Associate Professor of Law, University of San Diego School of Law. J.D., Yale Law School; B.A., B.S., University of Kansas. I am grateful for comments by Stacey Dogan, Ralph Folsom, Alan Palmiter, Dennis Patterson, Steven Schwarcz, Charles Wiggins, and participants in a presentation to the faculty of the Northeastern University School of Law on Mar. 23, 2000.

1. I define a market "crash" as a sudden and widespread downward movement in asset prices. I am primarily concerned here with markets in financial assets, including stocks and foreign exchange, although the analysis here may apply more generally to real assets including goods and services (a topic beyond the scope of this article). Financial assets present the problem of market crashes in its starkest form. Economists cite financial asset markets as examples of perfect competition, yet such markets are highly regulated and can generate widespread mania and panic. See R.H. CoASE. The Firm, the Market, and the LAw 9 (1990) (concluding that in financial markets "for anything approaching perfect competition to exist, an intricate system of rules and regulations would normally be needed"). Oddly, regulators shy from the pejorative "crash," referring instead to market "breaks," See Application of James D. Oberweis, Exchange Act Release No. 34-31213, S2 SEC Docket 1563, 1564 (Sept. 22, 1992) (referring to "market break" of October 1987); Statistical Series, Release No. 1953, 1964 SEC LEXIS 2260, at *3 (Jan. 28, 1964) (referring to "market break" of May 1962); T.I.S. Management Corp., Securities Act Release No. 1689, 1938 SEC LEXIS 427, at *7 (Feb. 25, 1938) (referring to "market break" of October 1929). I will use the term "crisis" to refer to the aftermath of a crash.

2. Financial market crashes lead to real economic losses. See discussion infra Part IV (describing the 1997 Asian financial crisis). For example, following the Great Crash of 1929, the negative net worth of failed banks in the United States was approximately $4 \%$ of the U.S. Gross Domestic Product (GDP). See Charles W. Calomiris, Blueprints for a New Global Financial Architecture, at 2 (Oct. 7, 1998) <http://www.house.gov/jec/imf/blueprnt.htm>.

3. The number and severity of global declines in financial asset prices have increased markedly during the past twenty years, especially during the 1990s. Since 1980, there have been nearly a hundred crises with at least the same real percentage cost as the 1929 crash (4\% of GDP), twenty crises with a cost greater than $10 \%$ of GDP, and ten with a cost greater than $20 \%$ of GDP. See id. Most of these crises have occurred outside the United States and Europe. The United States has not experienced a major financial crisis since 1933 (notwithstanding the 1987 stock market crash, which did not substantially affect GDP); the United Kingdom has not had such a crisis since 1866 . See Anna J. Schwartz, Real and Pseudo-Financial Crises, in FinanCIal. Crises and the World Banking System 11, 12 (Forrest Capie \& Geoffrey E. Wood eds., 1986). For a description of even earlier financial market participants and regulation, see MEIR KoHN. THE CAPITAL MARKeT Before 1600 (Feb. 1999) (Dartmouth College Dep't of Econ. Working Paper No. 99-06) (on file with the author). 
prices of Dutch tulip bulbs skyrocketed in frenzied futures ${ }^{4}$ trading during February 1637 (when a single Semper Augustus bulb sold for 5,500 guilders, equivalent to about $\$ 25,000$ today), and then collapsed to a fraction of their value. ${ }^{5}$ Likewise, finance scholars have been unable to agree about causes of the recent crises in Asia, ${ }^{6}$ the craze for Internet and technology stocks, ${ }^{7}$ or even more generally about what policy makers should do in the event of future market crashes. ${ }^{8}$

Moreover, although legal scholars have addressed numerous specific issues related to crashes, especially in the aftermath of the 1987 U.S. stock market crash, ${ }^{9}$ no legal academic has attempted to describe gener-

4. Futures are (exchange traded) forward contracts, which obligate one party to buy, and the other to sell, some item or instrument at a specified time and price. Futures are a low-cost means for parties to take leveraged positions in financial assets. Hence, they were an attractive instrument for tulip bulb speculators in the seventeenth century. For a discussion of the literature addressing tulip bulb speculators and similar speculative "bubbles," see Lynn A. Stout, Why the Law Hates Speculators: Regulation and Private Ordering in the Market for OTC Derivatives, 48 DUKE L.J. 701 (1999).

5. Compare Peter M. Garber, Tulipmania, 97 J. PoL. ECoN. 535, 555-57 (1989) (arguing that tulip bulb speculation was rational because the owner of a single rare bulb could profit from that bulb's offshoots) with Edward Chancellor. Devil Take the Hindmost: A History of Financial SPECULATION 14-27 (1999) (describing tulip speculation as an irrational euphoria or mania) and JoHN KenNeth Galbratth, A Short History of Financial. Euphoria 26-34 (1990) (same). The day the tulip bulb market crashed, February 3,1637, there was "no clear reason for the panic except that spring was approaching when delivery fell due [on the tulip bulb futures contracts] and the game would be up." Chancellor, supra, at 19. But see Nancy deWolf Smith, All's Well That Ends Like the Tulip Mania, WALL ST. J., Apr. 4, 2000, at A27 (describing limited consequences to tulip bulb crash).

6. The various crashes and crises in Asia began in July 1997, with the floating (and rapid devaluation) of Thailand's currency, the baht. The Asian crises are discussed infra Part IV. Notwithstanding the continuing debate among economists, it is worth noting that at a 1999 conference sponsored by the World Bank and the Brookings Institution, there was substantial agreement among the participants on several important points, including the importance of corporate governance failure as a cause. See discussion infra Part IV.

7. Internet and technology stocks have proven to be quite volatile. On Monday, April 3, 2000, the Nasdaq Composite Index, which includes many such stocks, fell 7.6\%. See E.S. Browning, Tech Sell-off Comes as DJIA Surges 300.01, WaLL ST. J., Apr. 4, 2000, at Cl. Consider, for example, stock in Yahoo! Inc., one prominent Internet corporation. As of April 3, 2000, Yahoo! Inc. stock (symbol YHOO) had a 52-week range of $\$ 55.00$ to $\$ 250.06$. See Nasdaq National Market Issues, Wall St. J., Apr. 4, 2000, at C15.

8. See Andrew Crockett, Why Is Financial Stability a Goal of Public Policy?, in MaIntaining Financial Stability in a Global Economy: a Symposium Sponsored by the Federal Reserve BANK OF KANSAS CTTY 7, 32 (1997) ("What to do when a significant "bubble' is thought to be developing, or when a bubble bursts, is a matter on which there is little agreement.").

9. See Tamar Frankel, What Can Be Done About Stock Market Volatility?, 69 B.U. L. Rev. 991, 999-1007 (1989) (arguing for creation of a "National Market Maker" to balance supply and demand during periods of market volatility); Jonathan R. Macey, The Fraud on the Market Theory: Some Preliminary Issues, 74 CORNELL L. Rev. 923, $923-26$ (1989) (reviewing and criticizing restrictions on short sales of stock). 
ally a theory of market crashes. This lack of interest in the "big picture" is ironic given the number of economists staking reputations on such theories (many of them based on dubious legal research) ${ }^{10}$ and the fact that the securities laws were responses to a crash, the Great Crash of 1929." Thus, we are faced with an odd state of scholarship, with economists dominating a debate that is, at its core, about law. This should not be. ${ }^{12}$ As Jeffrey Sachs of the Harvard Institute for International Development has noted-in remarks encouraging the American legal community to play a more active role in resolving existing crises- "the international economy is far too important to be left to the economists." 13

This article attempts to generate interest among legal scholars in two important, unanswered questions: First, why do markets crash? Second, what can law do about it? These questions may, like many other questions in law, be unanswerable-nevertheless, this article is an attempt to critique possible answers to the first question, and to recommend some answers to the second.

10. See infra text accompanying notes 116-32.

11. See Central Bank v. First Interstate Bank, 511 U.S. 164, 170-71 (1994) (noting that Congress passed the securities laws "[i]n the wake of the 1929 stock market crash"). In direct response to the outcry for regulation protecting individual investors following the Crash of 1929 , the seventythird Congress enacted two pieces of securities legislation: the Securities Act of 1933, 48 Stat. 74 (1933) (codified as amended at 15 U.S.C. $\$ 77$ (1994)), which regulates initial distributions of securities, and the Securities Exchange Act of 1934 (1934 Act), 48 Stat. 881 (1934) (codified as amended at 15 U.S.C. $\$ 78(1994)$ ), which among other things regulates post-distribution trading. See Blue Chip Stamps v. Manor Drug Stores, 421 U.S. 723, 752 (1975). The same type of crash-then-law sequence has occurred during the past several hundred years, with financial market regulation following largely as a response to market crashes. See Chancellor, supra note 5, at 20, 88, 148, 192, 221, 348-49. If markets did not crash, the entire corpus of law related to financial markets and transactions would be a primer.

12. Market crashes should be of special interest to lawyers and legal academics, even beyond how they affect our own pocketbooks (notwithstanding that this effect may be considerable). Law may play a critical role in preventing crashes and ameliorating their effects. Although the arguments have flaws, some commentators argue the Federal Reserve Board's governance of banks and the money supply has prevented a major U.S. banking crisis during the past six decades (ignoring, of course, the Savings and Loan debacle of the 1980s); others argue that so-called "circuit breakers" have prevented a major stock market decline since 1987 by providing market participants with a short window of time to catch their breath, pause, and reflect (and then, in all likelihood, to begin selling again). See discussion infra Part III.B.3. For a recent assessment of the Asian economic crisis by a legal academic, stressing the role of investors and creditors, see Ross P. Buckley, An OftIgnored Perspective on the Asian Economic Crisis: The Contribution of Creditors and Investors, Banking \& Fin. L. REv. (forthcoming Spring 2000) (on file with the author).

13. Jeffrey D. Sachs, Globalization and the Rule of Law, Yale Law School Occasional. PaPERS, SECOND SERIES, No. 4, at 16 (1998). Jeffrey Sachs has described the problems associated with the recent collapse in Asia, Russia, and Brazil as a "crisis of global capitalism," even capitalizing the terms. See id. at 14 ("We in fact have a Crisis of Global Capitalism, the problem of living in an intemational environment that lacks the rudimentary instruments to control financial panic."). 
I also will try to introduce two major branches of scholarship-one in finance, one in law-to each other. Finance and law often are ships passing in the night. Finance scholars assume away or oversimplify law. ${ }^{14}$ Ronald Coase is one recent and harsh critic of economists' assumptions regarding markets, especially as they relate to law. In Coase's view, economists ignore how law affects market transactions, ${ }^{15}$ how law is a necessary prerequisite to well-functioning markets, ${ }^{16}$ and-most importantly here-how law is a crucial part of exchange transactions in financial instruments. ${ }^{17}$ At the same time, legal scholars are not blameless either, and often have been oblivious to even blunderbuss economics, deciphering the complexities of finance breakthroughs years after the fact, or not at all. ${ }^{18}$

In two seemingly unrelated areas, finance and legal scholars have been developing powerful ideas that can provide deep insights into theo-

14. See discussion infra Part III.A.2.

15. See COASE, supra note 1 , at 5 ("One result has been that the crucial role of the law in determining the activities carried out by the firm and in the market has been largely ignored.").

16. See id. at 10. Coase states:

It is evident that, for their operation, markets such as those that exist today require more than the provision of physical facilities in which buying and selling can take place. They also require the establishment of legal rules governing the rights and duties of those carrying out transactions in these facilities. Such legal rules may be made by those who organize the markets, as is the case with most commodity exchanges. The main problems faced by the exchanges in this law making are the securing of the agreement of the members of the exchange and the enforcement of its rules. ... When the physical facilities are scattered and owned by a vast number of people with very different interests, as is the case with retailing and wholesaling, the establishment and administration of a private legal system would be very difficult. Those operating in these markets have to depend, therefore, on the legal system of the State.

17. See id. at 9. Coase states:

All exchanges regulate in great detail the activities of those who trade in these markets (the times at which transactions can be made, what can be traded, the responsibilities of the parties, the terms of settlement, etc.), and they all provide machinery for the settlement of disputes and impose sanctions against those who infringe the rules of the exchange. It is not without significance that these exchanges, often used by economists as examples of a perfect market and perfect competition, are markets in which transactions are highly regulated (and Id. this quite apart from any government regulation that there may be).

18. This belatedness is changing, in part because of an increase in collaboration by legal academics and economists, see, e.g., J.L. EcoN. \& ORG., a greater number of J.D./Ph.D. academics, and an improvement in availability of resources for both legal academics, economists, and others (e.g., through the Social Science Research Network, <http://www.ssm.com>). The contrast is sharp, for example, between the time it took efficient market theory to enter legal scholarship and the time it took path dependence theory to enter legal scholarship. Nevertheless, gaps remain. For example, economists continue to dominate scholarly work on derivatives and market microstructure, despite the importance of legal issues in these areas. 
ries of regulatory competition, corporate governance, and the causes of financial market crises. ${ }^{19}$ The first area-in finance-is the study of how corporate governance failure ${ }^{20}$ affects financial crises. Financial economists searching for causes of recent crises in East Asia, Russia, and Brazil have zeroed in on the failure of legal regimes in these so-called "emerging financial markets" 21 to protect investors' rights. Economists are beginning to notice that law-or more precisely the failure of legal rules and regimes to protect investors-may have played a larger role in these crises than they originally had anticipated. However, lawyers and legal academics are largely absent from the debate about financial crises. ${ }^{22}$ The commentary is dominated by economists, many of whom unfortunately vastly oversimplify or even misunderstand the role of law in recent crises. $^{23}$

The second area-in law-is the study of how regulatory regimes compete. ${ }^{24}$ Legal scholars have debated various theories of regulatory competition in corporate law for decades, although the debate about regulatory competition in the securities area has become especially heated since $1998 .{ }^{25}$ This debate is best known as race-to-the-top ${ }^{26}$ versus race-

19. However, legal scholars have not yet applied their ideas about regulatory competition to the debate about market crashes.

20. By "corporate governance failures" I mean market failures associated principally with two types of problems: agency costs and information asymmetry. The agency cost problem is that managers have different objectives from investors. For example, managers may want to maximize their own income and perquisites or the firm's size, while investors want to maximize their own profits. The information asymmetry problem is that managers are better informed than investors. For example, management has better information about expected future cash flows from a project than investors. See discussion infra Part II.C.3.

21. See Frank Partnoy, F.I.A.S.C.O.: Blood in the Water on Wall Street 77 (1997) (describing evolution of the term "emerging markets").

22. For example, a recent World Bank-Brookings Institution conference on emerging markets was dominated by economists discussing corporate governance failure (although one prominent legal academic, Kenneth Scott, was a commentator). See Kenneth E. Scott, Corporate Governance and East Asia: Korea, Indonesia, Malaysia, Thailand, in The First ANNUAl. World Bank GroupBrookings institution Conference: Financial Markets and Development: Preventing Crises in EMERGing MARKETS (Mar. 26-27, 1999) (on file with the author).

23. See discussion infra Part III.A.2.

24. This argument is separate from the more general argument about the goals of corporate and securities law. See discussion infra Part III.A., B.

25. See, e.g., Stephen J. Choi \& Andrew T. Guzman, Portable Reciprocity: Rethinking the International Reach of Securities Regulation, 71 S. CAL. L. REv. 903 (1998) (arguing for regulatory competition among national securities law regimes); Roberta Romano, Empowering Investors: A Market Approach to Securities Regulation, 107 YALE L.J. 2359 (1998) (arguing for regulatory competition among state securities law regimes within the U.S. and suggesting how this argument could be applied globally); Merritt B. Fox, Retaining Mandatory Securities Disclosure: Why Issuer Choice Is Not Investor Empowerment (1999) (Univ. of Mich. Law School Working Paper) (on file with the 
to-the-bottom, ${ }^{27}$ although several scholars recently have offered competing variations. ${ }^{28}$ Implicit in these arguments is the notion that law is a product which can be bought, sold, or traded, ${ }^{29}$ although the analysis of cross-border "trade" in legal rules remains largely unexplored.

How are corporate governance and regulatory competition related, either to each other or to market crashes? If corporate law benefits from competition among regulatory regimes (as some legal scholars say),,$^{30}$ then opening financial markets-especially emerging financial marketsto international regulatory competition may improve corporate governance and thereby decrease harm from crashes. On the other hand, if crashes have some other primary cause, or if international regulatory competition would lead to a race-to-the-bottom, opening financial markets (especially before an appropriate regulatory regime is in place) may exacerbate the problems of crashes.

These two perspectives are especially relevant to assessing the recent Asia crisis. In its aftermath, commentators and regulators have proposed a medley of laws and rules, with the International Monetary Fund, the World Bank, and senior treasury officials of many countries weighing in. ${ }^{31}$ As in the past, these proposals typically have drawn from the ideas of economists, not legal academics. ${ }^{32}$ As in the past, many are misguided. ${ }^{33}$

Legal commentators on regulatory competition have directed their proposals to the private sphere, where markets work reasonably well, rather than to the public sphere, where governments and supranational or-

author) (criticizing Romano and Choi \& Guzman proposals).

26. See Romano, supra note 25 , at $2384 \mathrm{n} .76$ (citing evidence supporting race-to-the-top interpretations); Ralph K. Winter, Jr., State Law, Shareholder Protection, and the Theory of the Corporation, 6 J. LEGAL. STUD. 251, 262-92 (1977) (same).

27. See Lucian Arye Bebchuk, Federalism and the Corporation: The Desirable Limits on State Competition in Corporate Law, 105 HARv. L. REv. 1435, 1448-50 (1992) (offering arguments supporting race-to-the-bottom interpretations).

28. See Bernard Black \& Reinier Kraakman, A Self-Enforcing Model of Corporate Law, 109 HARv. L. REv. 1911, 1974-77 (1996) (suggesting path-dependent evolution of corporate law); Ehud Kamar, A Regulatory Competition Theory of Indeterminacy in Corporate Law, 98 Colum. L. Rev. 1908, 1927-28 (1998) (suggesting development of corporate law based on vague, open-ended standards).

29. See Roberta Romano, Law as a Product: Some Pieces of the Incorporation Puzzle, 1 J.L. ECON. \& ORG. 225, 280-81 (1985) (analyzing supply and demand for corporate charters).

30. See Romano, supra note 25 , at 2384 n.76.

31. See infra note 150.

32. See Barry Eichengreen, Toward a New International Financial. Architecture: A Practical Post-Asia AGENDA 124-32 (1999) (summarizing sixteen separte proposals).

33. See discussion infra Part III.B (criticizing recent proposals). 
ganizations have oligopoly power. Applying the rationale that for private regulatory competition to create regulatory competition among public lenders would reduce market failure.

One final introductory note: In this article, I also advance a set of proposals designed to solve the problem of concentrated financial asset ownership among individuals, especially families. This problem had been ignored until recently, when several economists corroborated what many may have suspected in Asia: that a few large families owned and controlled much of the private sector. ${ }^{34} \mathrm{I}$ argue that such concentration of ownership leads to poor corporate governance, expropriation of minority shareholders, capture of regulators, increased cost of capital to firms, and-most importantly-to the sort of informational market failure that leads to market crashes. I suggest a few proposals for diluting this concentrated ownership, focusing on breaking up the families.

Part II discusses the question of why markets crash. Part III addresses the role of law in preventing or ameliorating the effects of market crashes, assesses current options, develops the idea of law as a product, extends the legal literature of regulatory competition theory, and suggests some new alternatives for using law to prevent market crashes, including proposals for encouraging dilution of financial asset ownership by families. Part IV applies these proposals to the recent Asia crisis and makes some additional recommendations.

\section{Why Markets Crash}

As noted in the Introduction, the question of why markets crash continues to perplex economists and market participants. If only we could time the market . . . . In this section, I explain how crashes are inconsistent with the theory of efficient markets. I then illustrate why crashes are so important, and describe three "market failure" rationales for crashes.

\section{A. The Argument That They Don't}

Many economists' first response to my point about the importance of market crashes is to deny the premise. The argument, simply put, is that markets don't crash. On its face, this argument appears absurd. It seems ludicrous to argue, for example, that a one-day decline of $22.6 \%$ in the Dow Jones Industrial Average, ${ }^{35}$ or a one-month decline of $80 \%$ in

34. See discussion infra Part III.A.3.

35. See Chancellor. supra note 5, at 269 (describing the magnitude of the 1987 U.S. stock 
the value of shares in the South Sea Company, ${ }^{36}$ was in fact a rational response to new information. ${ }^{37}$ Yet the school of thought known as the Efficient Market Hypothesis (EMH) not only proffers but requires just such an argument. ${ }^{38}$

Here is the theory: the EMH posits that stock prices reflect available information, in varying degrees. ${ }^{39}$ To the extent information is not reflected in stock prices, rational investors seeking profits buy and sell stocks until the information is reflected. This mechanism ensures that prices reflect available information, although the EMH theories vary in degree, based on the type of information reflected in prices..$^{40}$ If prices reflect available information, then prices will change only in response to new (i.e., previously unavailable) information. As a result, changes in prices should be essentially random responses to the revelation of new information (which also is essentially random). ${ }^{41}$

EMH proponents seeking to explain large market movements (up or down) have two choices. First, they can argue that such movements are responses to new information. Second, they can argue that there are certain low-probability exceptions to the EMH. Because the second argument is essentially an admission that the EMH does not apply to market crashes, ${ }^{42}$ I will focus here only on the various iterations of the first

market crash).

36. See Larry D. Neal, How the South Sea Bubble Was Blown up and Burst: A New Look at Old Data, in Crashes and Panics: The Lessons From History 33, 40-47 (Eugene N. White ed., 1990) (describing magnitude of the 1720 bursting of the South Sea bubble).

37. Crashes are often not fully explained by the introduction of new information. For example, the downward movement in the prices of Asian financial assets in July 1997 is not fully explained by new information associated with the devaluation of Thailand's currency, the baht. See discussion infra Part IV; see also John Kenneth Galbraith. The Great Crash 87 (1979) (noting that relevant negative information was available months prior to the Great Crash of 1929).

38. See generally Eugene F. Fama, Efficient Capital Markets: II, 46 J. FiN. 1575 (1991) (reviewing recent market efficiency literature).

39. See id. at 1575 .

40. For example, there are weak, semi-strong, and strong forms of the EMH, depending on whether the proponent of the theory believes that past prices, other public information, or non-public information is reflected in current prices; the more information is reflected in prices, the stronger the theory. See id. at 1601-02; Ronald J. Gilson \& Reinier H. Kraakman, The Mechanisms of Market Efficiency, 70 VA. L. REv. 549, 565-92 (1984) (describing types of efficiency). The EMH has been criticized on a number of grounds. See generally William K.S. Wang, Some Arguments That the Stock Market Is Not Efficient, 19 U.C. DAvis L. Rev. 341 (1986) (describing market anomalies that contradict the EMH); Jeffrey N. Gordon \& Lewis A. Kornhauser, Efficient Markets. Costly Information. and Securities Research, 60 N.Y.U. L. Rev. 761, 764-65 (1985) (criticizing the EMH). However, these criticisms are not relevant to my point that the EMH is inconsistent with market crashes. The problem of market crashes persists for EMH theorists even if the other criticisms are not correct.

41. See ChanCEllor, supra note 5, at 242.

42. The question remains why the EMH would not apply to market crashes. I address the rea- 
argument.

Large market movements can be explained as responses to new information in three ways. First, and most sensibly, economists attempt to demonstrate empirically that crashes have come in response to certain new information. One argument, for example, is that the Great Crash of 1929 was a response to new information about a crisis in global trade. Likewise, the 1987 U.S. stock market crash, the collapse in tulip bulb prices, and the South Sea bubble bursting all may be said to have been responses to new information. ${ }^{43}$

In each of these cases, the empirical argument is quite weak. ${ }^{44}$ The information that may have led to the market crash in each case was available to at least some market participants much earlier than the time of the crash. ${ }^{45}$ If the information was available earlier, there must be some explanation for why investors waited until a particular day to act on the information. One explanation may be investor irrationality, which is not consistent with the assumptions of the EMH. ${ }^{46}$

Second, economists have demonstrated mathematically that even under the assumptions of the EMH, there will be certain large and sudden movements in markets. ${ }^{47}$ According to these models, these events will not happen very often. ${ }^{48}$

sons why the EMH might not hold in such instances in Part II.C.

43. See, e.g., Garber, supra note 5, at 552-53.

44. See, e.g., Chancellor, supra note 5, at 215, 266-71. There is some evidence, however, that banking crises during the 1800 s were related to real events in general terms, although it is unclear whether any information about these real events was unavailable to depositors before the panic. This evidence supports a slightly different view: that crashes are natural accompaniments to the business cycle, as, for example, when depositors receive information about an economic downturn and withdraw funds. There is some empirical support for this view. See generally Franklin Allen \& Douglas Gale, Optimal Financial Crises, 53 J. Fin. 1245, 1249 (1998) (developing a model illustrating the role of business cycles in generating banking crises); Gary Gorton, Banking Panics and Business Cycles, 40 OXFord ECON. PAPERS 751 (1988) (finding evidence that banking panics since 1870 have related to the business cycle and therefore are not random events).

45. See, e.g., Galbraith, supra note 37 , at 78-79. Only a small percentage of market participants need access to such information for it to be reflected in market prices. See Romano, supra note 25 , at $2367 \mathrm{n} .21$ (describing studies).

46. See discussion infra Part II.C.1.

47. This view has become known as the theory of "rational bubbles." See Gary J. Santoni \& Gerald P. Dwyer, Jr., Bubbles or Fundamentals: New Evidence From the Great Bull Markets, in Crashes and Panics: Thi: Lessons From History 188, 190-95 (Eugene N. White ed., 1990). The first formal economic model of rational bubbles-sometimes referred to as the "sunspots" model (a reference to the extraneous variables said to cause panics)-was proposed in 1983. See Douglas W. Diamond \& Philip H. Dybvig, Bank Runs, Deposit Insurance, and Liquidity, 91 J. Pol. Econ. 401 (1983). For a review of this literature in finance, see Andrea Devenow \& Ivo Welch, Rational Herding in Financial Economics, 40 EUROPEAN ECON. Rev. 603 (1996).

48. See ChANCELloR, supra note 5, at 282 (citing probability of 1987 U.S. stock market crash, 
The mathematics supporting these models is, by definition, correct (as mathematics tends to be), although some of its assumptions seem dubious. ${ }^{49}$ However, the fact that such low-probability events occur under the theory makes the difference between the theory of rational bubbles and the theory of irrational bubbles a semantic one at best. ${ }^{50}$ Economists may feel more secure being able to slap a few mathematical formulas on the EMH to save the mathematical purity of the theory (and to account for obvious market crashes). But whether the theory is supported by mathematics or not, these low-probability large downward price movements continue to occur. A mathematical theory that low-probability large downward price movements occur is essentially the same as a nonmathematical theory that markets crash. ${ }^{51}$

Third, economists have argued that markets may crash due to government regulation. ${ }^{52}$ This is a slightly different version of the information asymmetry argument. It certainly is true that failed government policy or misguided regulation may create market distortions that correct themselves in a sudden fashion. For example, many economists argue that poor macroeconomic and government policies led to the misallocation of credit, which was primarily responsible for the crises in East Asia..$^{53}$ A similar argument is made regarding fixed exchange rate policies

according to proponents of this theory, at approximately $10^{160}$ to one, i.e., roughly the probability of one occurrence per twenty billion life spans of our universe).

49. However, there is a difference between saying the mathematics is correct and saying the mathematics reflects real world phenomena. When considered in real terms, the mathematics of rational bubble theory is counterintuitive, perhaps even ridiculous. The theory assumes financial asset prices follow paths that move off to either plus infinity or minus infinity, unlikely destinations even in an era of amazon.com and Yahoo! stock price volatility. See Robert J. SHLller. Macro Markets: Creating Institutions for Managing Society's LaRgest Economic Risks 47 (1993). As a result, some respected economists seem to take the theory with a grain of salt. See id. at 47 ("The possibility of rational speculative bubbles may be rather academic, since one might doubt that the market would ever develop an expectation that the price will go off to infinity unwarranted by fundamentals. Unless people feel that the bubble will go on forever, then it will not be rational for it ever to start.").

50. Economists of the rational bubble school simply substitute "low probability event" for "market crashes." In either case, the concern is with large-scale downward movements in the prices of financial assets.

51. Economists of the rational bubble school often describe crashes as random or self-fulfilling events; there is more than one equilibrium point, one of which leads to a crash. See, e.g., Devenow \& Welch, supra note 47 , at 606 . In fact, the mechanism this school uses to describe the crash is very similar to that of the cognitive error school. See discussion infra Part II.C.1. If everyone believes a panic is about to occur, it is optimal for each individual to withdraw; if no one believes a panic will occur, only individuals who need liquidity will withdraw. In this way, the phenomenon of a panic can be described as having multiple equilibria. See Diamond \& Dybvig, supra note 47, at 408-10.

52. See discussion infra Part III.A.2.

53. See EICHENGREEN, supra note 32, at 5-6, 19-21; Alan Greenspan, The Structure of the In- 
in Asia, particularly in Thailand, which made a rapid devaluation of the domestic currency inevitable. ${ }^{54}$

To the extent regulations are known well in advance of a crash, it is difficult to argue that there is some new information that leads investors to sell financial assets all at once. On the other hand, it may be the case that regulations prevent the market from reaching an equilibrium price, either by creating artificial supply or demand, or by imposing a price floor or ceiling. In the case of foreign exchange,,$^{55}$ the argument is that a government policy of fixing rates will prevent the market for foreign exchange from clearing, at least temporarily. ${ }^{56}$ Similarly, a government policy subsidizing the purchase of financial assets may skew the supply or demand for those assets. ${ }^{57}$ To the extent this argument is based on a market failure rationale, rather than on a new information rationale, it seems credible. $^{58}$

In sum, according to the EMH, markets are efficient, relative to some set of information, and market prices should reflect such information. It follows that the only possible explanation for large market movements (up or down) under the $\mathrm{EMH}$ is as a response to new information. However, the magnitude of market movements during times of crash is

ternational Financial System, Remarks to Annual Meeting of the Securities Industry Association (Nov. 5, 1998) <http:/www.bog.ffb.fed.us./boarddocs/speeches/1998/19981 105.htm>.

54. See discussion infra Part IV.

55. Of course, there are numerous different types of financial markets, all of which crash periodically, including markets for stocks, bonds, real assets, and derivatives, but the largest financial markets are the foreign exchange markets, with annual trading volume of more than $\$ 1.5$ trillion per day. See Jennifer Barrett, Foreign Exchange Market Upgrades Technology, WaLL ST. J., Jan. 26, 2000, at B15. Foreign exchange markets are also the most often blamed for recent financial market crises. See, e.g., Charles adams et al.. International Monetary Fund. International Capital MARKETS 44-50 (1998) (describing role of foreign exchange markets in Asian decline). Foreign exchange volatility depends greatly on a country's foreign exchange regime. In a fixed rate regime, the country (usually the Central Bank) stands ready to exchange local currency for foreign currency at some specified rate. See William J. Baumol \& Alan S. Blinder. Economics: Principles and Pol ICY 759 (3d ed. 1985). There are variations on the fixed rate regime, including, for example, currency bands and moving pegs. In each, the primary source of volatility relates to attempts by a country to maintain a particular fixed rate, usually in response to an "attack" on this pegged rate. See Crockett, supra note 8 , at 24 . In contrast, in a floating rate regime, the value of local currency in terms of foreign currency is set by forces of supply and demand. Floating rate regimes also are subject to volatility, although the sources of volatility are less clear. See id.

56. See BAUMOL \& BLINDER, supra note 55, at 759-60. Over time, supply and demand for foreign currency must be equal; as a consequence, an overvalued currency can only be maintained for a relatively short period of time. See id.

57. Consider, for example, what the effect on residential real estate prices would be if the U.S. government eliminated the interest deduction for homeowners.

58. I discuss the various market failure arguments related to market crashes in Part Il.C. 
inconsistent with this explanation. Therefore, the EMH does not hold during times of market crashes.

\section{B. Why It Matters If They Do}

Some scholars may respond to the argument that markets crash with: "so what?"s9 Just as every day trader gets his or her due, every market participant knows there is the potential for both loss and gain. The fact that markets decline $20 \%$ is no different from the fact that markets decline $2 \%$, or $0.0002 \%$. Of course, there are more (and bigger) winners and losers during crashes. But, the response goes, there are no real net losses, ${ }^{60}$ and over long periods of time the stock market remains the best investment, despite the risk of a market crash.

This response has two flaws. First, crashes are allocatively inefficient. Market efficiency is important because participants in an efficient market are able to transact at prices that reflect fundamental values. A financial system allocates resources among savers and borrowers. Prices change to reflect new information as it becomes available. To the extent prices do not reflect fundamental values, resources are misallocated as parties transact based on incorrect prices. Therefore, price movements beyond what is justified based on changed fundamentals will result in allocative inefficiency, and real costs.

Such allocative inefficiency is especially acute in financial markets-as compared to markets for goods and services-because financial assets are critical to savings and investment decisions, which drive the allocation of economic resources and economic growth. ${ }^{61}$ If financial asset prices do not reflect fundamental values, investors will be more uncertain about investing in such assets, particularly over the long term. Such uncertainty will hamper investment critical to real economic growth. If the financial system is inefficient, the economy is not operating efficiently and economic growth will be lower than it otherwise would have been. ${ }^{62}$

59. See Chancellor, supra note 5, at 271 (describing the view that market panics rarely cause depressions).

60. There is some evidence that following the tulip mania of 1637 most investors in tulips were little better or worse off than before the mania, primarily because investors held offsetting positions. See Smith, supra note 5, at A27.

61. See Crockett, supra note 8, at 12 ("Financial and other asset markets, because of their broad linkages to saving and investment decisions, obviously have a greater potential impact on other macroeconomic variables than do developments in markets for goods and services.").

62. Poverty and an inefficient financial system are related. See Frederic S. Mishkin, The Causes and Propagation of Financial Instability: Lessons for Policymakers, in MaINTAINING FInANcial Stabiltity in a Global Economy. A Symposium Sponsored by the Federal Reserve Bank of 
Second, financial instability is closely linked to real economic performance ${ }^{63}$ Financial instability, or excessive volatility, has real negative effects, and inefficiency in financial markets may be correlated with high financial asset price volatility. For example, financial institutions operating in volatile markets will face liquidity concerns during periods of sharp downward price movements. ${ }^{64}$ Problems in one financial market may spread quickly to other markets, a phenomenon often referred to as "contagion." 65

Conversely, financial stability can be thought of as a "public good." 66 The consumers of this good are users of financial services, including buyers and sellers of stocks and bonds, as well as bank depositors and financial intermediaries. Regulators can improve society's welfare by providing financial stability (i.e., avoiding crashes), just as they provide other public goods.

Thus, crashes matter in real terms. To the extent law can prevent crashes, society is better off. This is true whether the result is improved allocative efficiency or the provision of financial stability, a public good.

KanSAS CrTY 55, 56 (1997) ("Indeed, the economics literature on financial repression demonstrates that an important reason why many poor countries remain poor is that their financial sectors remain underdeveloped.").

63. For example, the Mexican currency crisis led to a severe recession and a collapse of the banking system. See Crockett, supra note 8 , at 8 (describing the adverse consequences of financial strain on several countries' economies, including Mexico).

64. See id. at 10-11. Even prudently run financial institutions, including banks, may be at risk of insolvency during periods of extreme price volatility. See id. at 12.

65. "Contagion" exists when, holding other relevant factors constant, a crisis in one country increases the likelihood of a crisis in another country. See Stanley Fischer, Commentary: Why Is Financial Stability a Goal of Public Policy?, in Maintaining Financial Stability in a Global Econ. omy, A Symposium Sponsored by the Federal Reserve Bank of Kansas City 37, 43 (1997). Although the causes of contagion are complex, there is abundant evidence supporting the existence of contagion. For example, during the period October 9-23, 1987, when the U.S. equity markets declined in value by approximately $20 \%$, most other major markets also suffered declines of similar magnitude: Canada (19\%), France (17\%), Germany (14\%), Japan (12\%), and United Kingdom (25\%). See Crockett, supra note 8, at 12-13; see also ADAMS ET AL.., supra note 55, at 49 (noting that from October 20-23, 1997, the Hong Kong stock market lost nearly one-quarter of its value, and on October 27, the Dow Jones Industrial Average lost 554 points).

66. A public good is a commodity or service which does not exhibit either "depletability" (i.e., if an additional user consumes a public good, the benefits of that good are not depleted) or "excludability" (i.e., it is difficult or impossible to exclude consumers from the benefits of a public good). See BAUMOL \& Blinder, supra note 55, at 543-44. Financial stability is not depletable because users of financial services who derive benefits from stability do not deprive others of such benefits. Financial stability is not excludable because users of financial services cannot be excluded from its benefits. Therefore, it is not uncommon for economists to argue that financial stability-like other public goods-should be provided by the government. See Crockett, supra note 8, at 14. 


\section{An Epistemology of Market Failure}

Given the above arguments in support of the existence and importance of market crashes, the question of what causes these phenomena remains. Most economists seeking to explain why financial asset prices diverge periodically from the realistic expectations of parties with available information have settled on one or more market failure-related rationales. ${ }^{67}$ Unfortunately, these rationales often differ crash-by-crash ${ }^{68}$ or asset class-by-asset class. ${ }^{69}$ Despite the fact that the literature on crashes is voluminous and repeats certain core themes, there is no clear theory of why markets crash.

In this section, I describe three explanations of why markets crash. I label these the "cognitive error," "moral hazard," and "information asymmetry" theories. Each theory presumes a market imperfection. "Cognitive error" arguments presume that investors are irrational in some way, either because they follow a herd mentality or mob psychology, or because they misperceive risk and reward. "Moral hazard" arguments presume that investors believe, correctly or not, that some entity ${ }^{70}$ is providing a guarantee, implicit or explicit, against a portion of their loss, thereby encouraging them to overinvest or to assume excessive risk. "Information asymmetry" arguments presume that investors are not aware of certain information critical to their investment decisions, and that they sell when they learn of this information.

67. See Robert J. Shiller. Irrational. Exuberance (2000) (arguing that structural, cultural and psychological factors contribute to irrational bubble markets).

68. See, e.g., GalbratTH, supra note 37, at 177-87 (citing the speculative excess of the 1920s and numerous economic factors as causes in concluding that " $[\mathrm{h}] \mathrm{ad}$ the economy been fundamentally sound in 1929 the effect of the great stock market crash might have been small"). Galbraith has been a leading commentator on market crashes for nearly fifty years. He attributes different causes to each speculative episode/crash he analyzes (e.g., for tulipmania, the beauty and wonder of tulip bulb colors; for the South Sea Bubble, the fascination with the joint-stock company and international trade). See GALBRAITH, supra note 5, at 28, 43-49. Although Galbraith has tried to connect various crashes, the "common denominators" he attributes to crashes generally, while colorful, do not form much of an economic theory. See id. at 13 (citing "the extreme brevity of the financial memory" and "the specious association of money and intelligence").

69. For example, economists have cited very different theories related to the collapse of banks. See generally Diamond \& Dybvig, supra note 47 (describing economic theory of banking crises), foreign exchange regimes; see also EICHENGREEN, supra note 32, at 133-41 (describing "How Economists Understand Crises" in the context of the collapse of foreign exchange regimes), and the markets for financial instruments. ChanCELLOR, supra note 5, at 328-335 (describing theories for stocks, bonds, and derivative securities).

70. For example, investors in an emerging market might perceive that both the United States and/or the International Monetary Fund would rescue market participants in the event of financial crisis. 


\section{Cognitive Error}

First, markets may crash due to the cognitive error of investors, ${ }^{11}$ typically following a period of irrational investor mania. The most prominent proponent of this view is the economic historian Charles P. Kindleberger, ${ }^{72}$ whose work reflects ideas generated earlier by Hyman P. Minsky, ${ }^{73}$ Irving Fisher ${ }^{74}$ and Charles Mackay. ${ }^{75}$ Although the cognitive error school has existed for many decades, recent research has confirmed its application to financial markets. ${ }^{76}$ Central to the cognitive error theory

71. The term "cognitive error" refers to actions by investors that are irrational or based on a misperception of expected losses and gains.

72. See Charles P. Kindlederger. Manias. Panics, and Crashes: A History of Financial. Crises 23-34 (3d ed. 1996) [hereinafter Kindleberger. Manias. Panics. and Crashes] (explaining the anatomy of typical crises and arguing for the role of a lender of last resort); see also Charles P. Kindleberger. The international. Economic Order: Essays on Financial. Crises and interna. tional Public Goods (1988); Charles P. Kinileberger, Keynesianism vs. Monetarism and Other Essays in Financial history (1985); Financial Crises: Theory, History and Policy (Charles P. Kindleberger \& Jean-Pierre Laffargue eds., 1982).

73. See Hyman P. Minsky, The Financial Instability Hypothesis: Capitalistic Processes and the Behavior of the Economy, in Financial. Crises: Theory, History and Policy 13-29 (Charles P. Kindleberger \& Jean-Pierre Leffargue eds., 1982).

74. See Irving Fisher, The Purchasing Power of Money: Its Determination and Rei.ation to Credrt. Interest and Crises (Augustus M. Kelley Publishers 1971) (2d ed. 1922).

75. See Charles Mackay, Memoirs of Extraordinary Delusions and the Madness of Crowds (1852).

76. See Ben Jacobsen, Irrational Trading in a Financial Market (unpublished working paper, University of Amsterdam) (on file with the author) (1999). One recent study by Jacobsen reported an extraordinary finding: that in an experimental financial market, more than $50 \%$ of the traders acted irrationally (in the sense that they violated the basic proposition that people prefer more to less) at least $10 \%$ of the time, although the impact of this irrationality was small and prices were not affected.

Similarly, Amos Tversky and Daniel Kahneman have shown that people exhibit loss-aversion (they consider the impact of losses to be greater than the impact of gains). See Amos Tversky \& Daniel Kahneman, Loss Aversion in Riskless Choice: A Reference-Dependent Model, 106 Q.J. EcoN. 1039 , 1054-58 (1991). For example, a person might choose a $100 \%$ chance of a $\$ 100$ gain over a $50 \%$ chance of a $\$ 200$ gain, but choose a $50 \%$ chance of a $\$ 200$ loss over a $100 \%$ chance of a $\$ 100$ loss, even though all of the choices have equivalent expected values. One explanation for lossaversion is that the value of a good to an individual increases when it becomes part of their endowment. See Daniel Kahneman et al., Experimental Tests of the Endowment Effect and the Coase Theorem, $98 \mathrm{~J}$. PoL. ECON. 1325, 1326 (1990). Loss-aversion in turn is given as an explanation for why bid prices (the prices at which market makers are willing to buy, i.e., the prices at which investors will be able to sell) are closer to the fundamental value of financial assets than ask prices (the prices at which market makers are willing to sell). See id. A possible explanation: owners of shares tend to overvalue the shares they possess, while traders are willing to pay only fundamental value for those shares.

Other recent studies have found that some of the largest one-day swings in financial asset prices during the Asia crisis cannot be explained by news events, but instead were driven by herd behavior, see Graceiela L. Kaminsky \& Sergio L. Schmukler, What Triggers Market Jitters: A Chronicle of the Asian Crisis, Board of Governors of the Federal Reserve System: Int'l Finance Discussion Papers, 
is the notion that panics and crashes are endemic to financial markets.

According to the cognitive error theory, markets move through several stages of progressively increasing investor irrationality, which ultimately is corrected in a crash. ${ }^{77}$ First, a "displacement" 78 creates new opportunities for profit (and therefore new opportunities to reallocate capital). Displacements are difficult to spot when they occur. For example, technological change (e.g., the invention of railroads or the spread in the use of the Internet for commerce) may or may not be the sort of displacement that leads to a panic.

Second, the amount of credit in the economy expands as additional capital is allocated to these new profitable ventures. ${ }^{79}$ The expansion of credit may be crucial for real economic growth. On the other hand, the new credit may be tomfoolery, based on investors' misperceptions of the value of technology. Again, the difference is difficult to spot ex ante. ${ }^{80}$

Next, financial asset prices rise, creating new opportunities for profit (and therefore new opportunities to reallocate capital). ${ }^{81}$ At some point the price increases create investor euphoria, which may be indistinguishable from wise investor decisionmaking. ${ }^{82}$ As more people buy into these

No. 634, at 21 (Apr. 1999), and that market bubbles may occur when short-selling is restricted and when traders have different expectations about the expected price path of a financial asset. See Stout, supra note 4, at 753-62. Professor Stout's theory is predicated upon the existence of some market imperfection, see id. at $757 \mathrm{n} .219$, and is therefore consistent with the cognitive error model of market panics and crashes.

77. See Kindleberger. Manias. Panics. and Crashes, supra note 72, at 11-16.

78. Both Hyman Minsky and Charles Kindleberger have used the term "displacement" to describe the exogenous change or shock that changes profit opportunities and thus leads to a speculative boom. See id. at 12 (citing as examples of such "displacement" the outbreak or end of war; a bumper harvest or crop failure; the widespread adoption of inventions such as canals, railroads, and automobiles; and major or surprising political events).

79. In most cases, the sources of additional credit have been banks, although in the United States the capital markets have played a more prominent role in allocating credit in recent decades. See Kindleberger. Manias. Panics, and Crashes, supra note 72, at 12.

80. As an example, consider priceline.com Inc., an Internet-related company whose website holds auctions for empty airline seats. Should such a one-year-old company have a market capitalization greater than that of Delta Air Lines, US Airways and United Airlines-combined? See Dean Foust \& Linda Himelstein, Time to Buy Net Stocks?, Bus. WK., May 17, 1999, at 118 (citing comparable values). It is difficult to say whether the market capitalizations of many Internet-related companies are justified based on technological change, or instead are reflections of investor mania.

81. Minsky and Kindleberger refer to this stage of speculative excess as "euphoria." KINDleberger, Manias, Panics. and Crashes, supra note 72 , at 13 . As potential investors observe others generating profits during this period, they, too, want to invest. As Kindleberger quips, "[t]here is nothing so disturbing to one's well-being and judgment as to see a friend get rich." Id.

82. To cite another recent example, were buyers of shares of Amazon.com Inc., which began as an Internet bookseller in 1997, savvy or naïve (or lucky)? An investment of $\$ 10,000$ in mid-1997 would have been worth more than $\$ 500,000$ less than two years later. See <http://www.quicken.com/ 
new ventures, including people who normally would not take on such risks, "mania" takes hold, and the prices of financial assets increase in a speculative "bubble." 83

Finally, at the top of the market, a few savvy investors decide to sell and prices stop increasing. Typically, there is a signal (e.g., bank failure, poor earnings at a key firm, or an unusual fraud) which leads speculators to realize the game is over. They sell, in a rush to the exits, ${ }^{84}$ and prices plummet. Panic continues until one or more of three things happens: (1) prices fall so low that some investors begin buying and support the market, (2) trading is halted, ${ }^{85}$ or (3) a lender of the last resort persuades the market that money will be available to meet the demand for cash from sellers. ${ }^{86}$

The cognitive error theory allows for differences between crashes as to the nature of the displacement, the form of credit expansion, and the type of object of speculation. (The tulip bulbs of the 1600 s become the Yahoo!s of 2000.) However, although the details of each crash may vary, the cognitive error school argues that there nevertheless will persist a certain pattern or structure to crashes generally, fueled by investor irrationality: displacement, credit expansion, mania, panic, and-finally-crash.

\section{Moral Hazard}

An alternative view is that markets crash due to distortions caused by financial guarantees. ${ }^{87}$ Financial guarantees, like insurance, create moral hazard problems. ${ }^{88}$ Traces of moral hazard problems have been

investments/charts/?symbol=AMZN> (visited Aug. 4, 1999).

83. Again, the terminology ("mania" and "bubble") is from Minsky and Kindleberger. See Kindleberger, Manias. Panics. and Crashes, supra note 72, at 14. By its nature, a speculative bubble is based on irrational behavior (i.e., investors' cognitive error), although again such phenomena are difficult to identify, except in hindsight.

84. See Nicholas D. Kristof \& Sheryl WuDunn, Of World Markets, None an Island, N.Y. TIMES, Feb. 17, 1999, at Al (describing the problem of investors "rushing to the exits" during the economic crisis in Asia).

85. In the U.S., trading may be halted by the relevant stock exchange. In addition, there are so-called "circuit breakers," which automatically halt trading in all stocks when the market declines by a certain amount in one day's trading session. See infra Part III.B.3.

86. See Kindleberger. Manias. Panics, and Crashlis, supra note 72, at 15. Kindleberger has been the leading proponent of a lender of last resort as a solution to market crises, including on an international level. See id. at 146-89.

87. For a general discussion of the role of guarantees in financial markets, see Robert $\mathrm{C}$. Merton \& Zvi Bodie, On the Management of Financial Guarantees, 21 FIN. MGMT. 87 (1992).

88. Moral hazard refers to the taking of excessive risks in the presence of insurance. See SHIL LER, supra note 49, at 1 (stressing the significance of inefficiencies created by insurance and moral hazard). 
found in the histories of the most severe financial crises. ${ }^{89}$ Guarantees create incentives for market participants to take on imprudent risks, with the expectation that they will receive support in the event of a crash. Accordingly, the moral hazard theory predicts that financial markets may be subject to periodic manias, panics and crashes. ${ }^{90}$

Financial guarantees may be explicit or implicit. Explicit guarantees are rare. For example, certain government sponsored entities, such as the Overseas Private Investment Corporation, will provide (for a fee) guarantees against default by certain debtors. ${ }^{91}$ However, especially in the context of emerging markets investing, it is more likely that guarantees are implicit. Supranational organizations (e.g., the International Monetary Fund or the World Bank) may encourage the notion that investors or governments are likely to receive assistance in times of crisis. Even if these organizations make no representations regarding any guarantee, if investors perceive that the organizations are likely to bail them out in a crisis, the same moral hazard problems will ensue.

Moral hazard problems may stem from the behavior of both lenders (investors) and borrowers (issuers). As to investors, guarantees create incentives to take on excessive risks. For example, based on the U.S.-led Mexican bailout of 1994-95, international mutual funds and hedge funds may have believed they would receive similar protections in the event of crisis. Given this perception, such funds would have been willing to take on much larger, and much riskier, positions in emerging markets financial instruments.

As to issuers, guarantees create incentives to borrow excessively, given the artificially low cost of capital resulting from increased investor demand. For example, suppose emerging markets issuers faced increased demand from investors who believed their investments were protected by guarantees. Such issuers would be able to borrow larger amounts at

89. See Michael Adler, Emerging Markets Investing: Problems and Prospects, in The First Annual World Bank Group-Brookings Institution Conference: Financial Markets and Development: Preventing Crises in Emerging Markets, at 5, 8-13 (1999) (on file with the author) (citing numerous proposals and plans for dealing with crises).

90. The idea that moral hazard may lead to a mania-panic-crash cycle is consistent with the cognitive error theory. The primary difference between the theories is that the moral hazard theory is explicit in blaming financial guarantees for starting the manic phase.

91. Similarly, parent corporations may guarantee the debts of subsidiary corporations, and certain other entities sell credit insurance or credit derivatives that effectively provide similar guarantees. See Frank Partnoy. The Siskel and Ebert of Financial Markets? Two Thumbs Down for the Credit Rating Agencies, 77 WASH. U. L.Q. 619, 670-72 (1999). In fact, any risky loan may be thought of as a combination of a default-free loan plus a guarantee. See Merton \& Bodie, supra note 87 , at 88 . 
lower cost than they otherwise could. Moreover, issuers could then become investors by using borrowed funds to purchase risky financial instruments with the same guarantees.

In addition, there is the problem of government moral hazard. ${ }^{92}$ Significant net debtor governments face incentives similar to those faced by shareholders of a firm with large debts. Such governments may take on excessive economic risks that cannot be sustained over time (e.g., maintaining a fixed overvalued currency, running large current account deficits, borrowing large amounts in foreign currency with short-term maturities, or allowing foreign exchange reserves to dwindle). ${ }^{93}$ These risks may be the backdrop for investor behavior that leads to a crash.

Several economists have proposed models in which moral hazard leads financial asset prices to artificially high levels, which prove to be unsustainable. ${ }^{94}$ However, there are no direct empirical tests of how important moral hazard problems have been in stimulating the surge of capital flows preceding a crash. ${ }^{95}$ Moreover, although moral hazard explains why market participants might take on excessive risk, it does not explain why the correction in asset prices must be sudden, as in a crash. For this explanation, the theory must rely on cognitive error theory and the "rush to the exits" phenomenon.

One final point about moral hazard: the moral hazard theory poses an interesting puzzle. The argument that moral hazard leads to market crashes also is an argument against two commonly proposed solutions to the problem of crashes: deposit insurance and the lender of the last resort. Paradoxically, crashes were more common in the United States before the existence of these two solutions. The United States was hit by substantial banking panics nearly every decade before the 1930s, but

92. Robert Shiller has raised the issue of government moral hazard in the context of his proposal for "macro markets" to allow individuals to hedge risks associated with fluctuations in national incomes. See SHILLER, supra note 49, at 2-3 (describing risk of the government "cheating" by mandating vacations and thereby manipulating the national income). Shiller also noted that the problem of government moral hazard is present in existing financial markets, although he believes such market failure "has not prevented these markets from functioning." Id. The issue here is not whether government moral hazard would prevent financial markets from functioning; rather, the issue is whether moral hazard might lead to excessive government risk taking, which might precipitate a crash.

93. Many current proposals for reform in emerging markets are based on attempts to link additional lending to changes in policies that involve excessive economic risks. See infra Part III.B.3.

94. See ADAMS ET AL., supra note 55, at $69-70$ (citing research by the economists Michael P. Dooley and Paul Krugman)

95. See id. at 70. 
none thereafter. ${ }^{96}$ Is it merely a coincidence that banking panics stopped at the same time the federal government created federal deposit insurance and the Federal Reserve Bank, ${ }^{97}$ the U.S. lender of last resort, and thereby increased the amount of moral hazard? If the moral hazard explanation is correct, shouldn't these safety net programs have increased the number of panics?

One possible solution to this puzzle is that markets require a certain amount of protection (and therefore must swallow a certain amount of moral hazard) to prevent crashes. Maintaining investor and depositor trust is another important factor. ${ }^{98}$ Because the amount of moral hazard is directly related to the information gap between borrowers and lenders, as this information gap has narrowed (due to advances in technology, and both disintermediation-the opening up of banking functions to competition-of and reduced dependence on banks), the quantity of moral hazard created by these safety net programs actually may have declined since the 1930s. Certainly, federal deposit insurance appears to play a minimal role in fostering moral hazard.

\section{Information Asymmetry}

Finally, there is the view that markets crash because of the information gap between investors and issuers. Issuers necessarily have better information than investors about risks and expected returns. This information gap is endemic to financial markets, and scholars justify much financial market regulation by reference to this gap..$^{99}$ For example, the ongoing debate about mandatory disclosure is at its core a debate about this information gap and informational efficiency. ${ }^{100}$

96. See Sachs, supra note 13 , at 11 .

97. See id. at 11-12.

98. See discussion infra Part III.A.1. For a possible solution to the moral hazard problem in this context, see Steven L. Schwarcz, Sovereign Debt Restructuring: A Bankruptcy Reorganization Approach, 85 CORNELL L. REv. 956 (2000) (advocating international convention for sovereign debt restructuring) (on file with the author).

99. See Fox, supra note 25 , at 4 (citing support for mandatory disclosure based on the information gap between investors and issuers).

100. Many legal scholars have concluded that despite its problems a mandatory disclosure regime of some kind is justified. See John C. Coffee, Jr., Market Failure and the Economic Case for a Mandatory Disclosure System, 70 VA. L. Rev. 717, 721 (1984); Frank H. Easterbrook \& Daniel R. Fischel, Mandatory Disclosure and the Protection of Investors, 70 VA. L. Rev. 669, 674-75 (1984); Fox, supra note 25, at 4. But see Jonathan R. Macey, Administrative Agency Obsolescence and Interest Group Formation: A Case Study of the SEC at Sixty, 15 Cardozo L. Rev. 909, 928 (1994); Romano, supra note 25 , at $2373-81$. 
My principal goal here is not to rehash the debate about whether mandatory disclosure is justified, a debate that increasingly has become rooted in empirical study. ${ }^{101}$ Instead, I am seeking to explain specifically how information asymmetry may lead to the particular set of problems associated with market crashes. ${ }^{102}$ Although these arguments are closely related to the mandatory disclosure arguments, they are not dependent on the same empirical studies, which do not focus on crashes.

According to the information asymmetry argument, there is a divergence between financial asset prices and fundamental value because investors lack sufficient information to analyze their investments. ${ }^{103}$ To the extent this information gap results in investors undervaluing financial instruments, issuers will close the gap by disclosing positive information to encourage investors to pay more. However, to the extent investors are overvaluing financial instruments, issuers may not have the same incentives to disclose. ${ }^{104}$

As some investors overpay for financial instruments, and market prices diverge from reality, both current investors and issuers have an incentive to keep negative information out of the market. New buyers watch prices increasing and decide they, too, must be part of this upward spiral. ${ }^{105}$ Thus, the information asymmetry theory draws (at least in part) on notions of investor cognitive error. Investor mania ends in panic and crash, as it does under the cognitive error theory.

The information asymmetry theory works better in the context of day-to-day corporate management decisionmaking, or even in securities issuance, than in the context of market crashes. Information asymmetry arguments dovetail with the rational bubble school explanations of why markets do not crash, and carry some of the same flaws. ${ }^{106}$

101. Compare Fox, supra note 25 , at $29-47$ (reviewing literature and concluding that mandatory disclosure is justified based on extensive studies), with Romano, supra note 25, at 237381 (reviewing essentially the same studies and reaching the opposite conclusion).

102. Similarly, the same information gap arguments can be used to assess financial market regulation in other areas, e.g., derivatives. See Frank Partnoy, Financial Derivatives and the Costs of Regulatory Arbitrage, 22 J. CORP. L. 211, 244-45 (1997).

103. See id.

104. Rational investors will realize issuers face these incentives and should discount the price they are willing to pay for financial instruments to reflect the uncertainty about whether issuers are disclosing all negative information. This "lemons problem" is a major flaw in the information asymmetry argument.

105. An additional flaw in the information asymmetry argument is that insiders at issuers who know of negative information could sell their stock, or even sell short shares, so that prices would reflect information available to issuers (i.e., so that prices were close to fundamental value). However, restrictions on insider trading or short selling would prevent such adjustment.

106. See supra note 47 and accompanying text. 
The theory also ignores the fact that issuers may not have good information either. The assumption of perfect information does not hold, even in modern financial markets, so the fact that investors do not have adequate information does not necessarily mean that issuers do. If neither issuers nor investors have adequate information, information asymmetry becomes less relevant. Instead, it is the information unavailability that may lead investors to overpay for financial assets. Nevertheless, the information gap is a necessary piece of the investor mania puzzle, even if it cannot explain the crash itself. To the extent investor decisions are rational, investors' willingness to "overpay" for financial assets must be based on an information gap.

\section{What Law Can Do About It}

Given the above theories of why markets crash, what can law do about crashes? In this Part, I offer answers to this question, beginning with an analysis of the proper role of law in financial market regulation. I then critique the current ways in which legal rules are applied to prevent crashes.

\section{A. The Role of Law}

Recall that investors face both agency and information costs in making investment decisions. ${ }^{107}$ One, perhaps traditional, role for law is to minimize these costs. There are others. In this section, I discuss some alternative conceptions of the role of law in financial markets.

\section{Trust}

Trust might seem an odd starting point for a discussion about the role of law in financial markets. Yet trust plays a key role in the formation and function of financial markets. ${ }^{108}$ In fact, trust can be seen as the crucial element in preserving a viable financial market.

Why is this the case? A primary reason is that financial systems are inherently unstable. Lenders want liquidity, but borrowers want long-term contracts. There is a maturity mismatch inherent in the functioning of a financial market. ${ }^{109}$ Lenders cannot both provide long-term contracts and

107. See supra note 20.

108. See Raphael La Porta et al., Legal Determinants of External Finance, 52 J. Fin. 1131, 1150 (1997) ("It is possible that some broad underlying factor, related to trust, influences the development of all institutions in a country, including laws and capital markets.").

109. For example, banks have illiquid or long-term assets (e.g., loans) and liquid liabilities (e.g., deposits). One might question why individuals would deposit money with banks. One possible 
receive liquidity. Borrowers cannot both provide liquidity and receive long-term contracts.

Therefore, one role of a financial system is to bridge this gap by providing an illusion to both lenders and borrowers. To the lenders the financial system gives the illusion of liquidity (although the truth is that if all lenders sought liquidity simultaneously, as in a bank run, liquidity would not exist). ${ }^{110}$ To the borrowers the financial system gives the illusion of a long-term contract (although the truth is that borrowers may or may not be able to "roll over" their loans for the same maturity they might have specified in an actual long-term contract). The illusion of a well-functioning financial system is supported by the law of large numbers, the assumption being that, of the large number of lenders, only a few will seek liquidity simultaneously. In short, financial market equilibrium is an act of faith.

For the United States in the nineteenth century, this illusion of trust could not be preserved, and panics and crashes occurred with great regularity. The United States experienced a financial crisis roughly every decade through the 1930s. ${ }^{111}$ Since then, an environment of trust has preserved this illusion, buttressed by deposit insurance and the Federal Reserve Bank's pledge to act as a lender of the last resort, and notwithstanding the fact that these institutions create moral hazard.

However, in emerging markets, the illusion has not been preserved, and many countries outside the U.S. and Europe continue to experience banking crises and panics. Between 1980 and 1996, 73\% of International Monetary Fund member countries experienced some form of banking crisis. ${ }^{12}$

answer is that banks have a comparative advantage in investing in illiquid, long-term, risky assets because banks are able to differentiate and price credit risks better than other intermediaries. Another possible answer is that banks have a comparative advantage due to state or government support. Deposit insurance, implicit guarantees and favorable regulatory treatment all give banks an advantage, even if bankers are not particularly good at differentiating and pricing credit risks. In any event, banks certainly have played and continue to play a more important role in emerging markets than in more developed markets, especially the United States.

110. A bank run occurs when many or all depositors attempt to withdraw their funds simultaneously. See Allen \& Gale, supra note 44 , at 1245.

111. See id. at 1245-46. Before 1900, banking panics were common in Europe and the United States until central banks were created to eliminate the problem (although the first central bank was the Bank of Sweden established more than 300 years ago). See id. at 1245. Banking panics occurred in September 1873, June 1884, November 1890, May 1893. October 1896, and October 1907, each panic triggering a recession of varying magnitude. See id. at 1245-46.

112. See id. at 1246 (citing Carl-Johan Lindgren et al., Bank Soundness and Macroeconomic Policy (IMF 1996)). 
To some extent the importance of trust is a sign that law is less likely to be relevant in financial markets than in other areas. Transaction costs in financial markets are low, liquidity high. Parties interact in continuous relationships governed by reputational considerations. There is abundant evidence that financial market participants contract around law. ${ }^{113}$

On the other hand, law may help nurture these types of relationships or solve collective action problems. Law may mimic rules evolving through private ordering, and therefore may reinforce the spirit of trust necessary for cooperative repeat-play relationships. Law could attempt to influence investor expectations ex ante to avoid the mania stage. In any event, trust is an important consideration not often recognized by those considering the role of law in financial markets. In an atmosphere of trust, law will be less necessary. Conversely, an important role of law is to preserve trust. ${ }^{114}$

\section{Governance}

A more traditional role of law is to minimize agency and information costs. In corporate and securities law, one solution to the problem of conflicts between shareholders and managers is corporate governance. Agency costs arise because managers have different incentives than shareholders. Information costs arise because managers are better informed than shareholders regarding the firm's expected future cash flows. Corporate governance measures are designed to reduce these costs either by aligning managers' incentives with those of shareholders, or by establishing devices to monitor managers. ${ }^{115}$

In the same way they are used to reduce agency and information costs, corporate governance measures can be used to reduce the probability of market crashes. Interestingly, this idea originated not with legal academics, but with finance scholars, who recently have added cor-

113. See generally Partnoy, supra note 102 (discussing regulatory arbitrage practices).

114. See generally Lawrence E. Mitchell, Trust. Contract. Process., in Progressive CorpoRATE LAW 185-217 (Lawrence E. Mitchell ed., 1995). Trust also improves liquidity. Trusting lenders and borrowers are more willing to transact, and increased secondary market liquidity leads to a lower bid-ask spread, which lowers the overall cost of capital (i.e., the market's required rate of return on the issue). See Rene M. Stulz, Globalization of Equity Markets and the Cost of Capital, SBF/NYSE Conference on Global Equity Markets, at 26 (1999) (on file with the author); see also Yakov Amihud \& Haim Mendelson, Asset Pricing and the Bid-Ask Spread, 17 J. FIN. EcoN. 223 (1986) (showing that the bid-ask spread affects the market's required rate of return on securities).

115. See Stulz, supra note 114, at 17-19. 
porate governance to their list of explanations for market crises. ${ }^{116}$ Specifically, their argument is that corporate governance failure both causes and exacerbates market crises. ${ }^{117}$ This argument stems from both anecdotal evidence and economic studies of the recent market crises, particularly in Asia.

Andrei Shleifer and Robert Vishny began the debate in finance about the role of corporate governance in a survey they published in 1997, just before the Thai baht devaluation of June $1997 .{ }^{118}$ From an academician's perspective, their timing could not have been better. The Asia crisis immediately followed, and financial economists began working to provide empirical support for the proposition that the quality of a country's corporate governance is related to its economic performance, including how firms are funded and owned. A related concept emerged: that poor enforcement of shareholder rights may be correlated with underdeveloped capital markets. ${ }^{119}$

One major study by Raphael LaPorta, Florencio Lopez-de-Silanes, Andrei Shleifer and Robert Vishny of the legal rules protecting shareholders and creditors in forty-nine countries concluded that common law governance rules tend to protect investors more than civil law rules. ${ }^{120}$ They also found that enforcement is weaker under civil than common law. ${ }^{121}$ In a separate study, the same economists found that the legal environment has been an important factor in determining the size and extent of financial markets, and that common law has led to larger and deeper financial markets than civil law. 122

116. See Andrei Shleifer \& Robert Vishny, A Survey of Corporate Governance, 52 J. FiN. 737 (1997).

117. See EICHENGREEN, supra note 32, at 19-21.

118. See Shleifer \& Vishny, supra note 116.

119. See supra note 22.

120. See Raphael La Porta et al., Law and Finance, 106 J. Pol. Econ. 1113, 1151 (1998). There are reasons to believe this study, as well as others performed by members of this same group. are seriously flawed. The study's authors rely on various numerical measures (each ranked on a scale of one to ten) such as: the efficiency of the judicial system, the rule of law, the level of corruption, the risk of expropriation, the risk of repudiation of contracts by the government. See id. at 1124-25. It is difficult, if not impossible, to quantify a country's legal regime on such a scale with any hope of accuracy, and such data are not helped by a sophisticated econometric model. Moreover, many of these numerical measurements are outdated, and are not appropriate for conclusions based on anecdotal evidence from the 1990s. To be fair, the authors are clear about the limits to their data and the assumptions underlying their conclusions. However, these limitations and assumptions may appear less serious to economists than to legal commentators more sensitive to the complexities of legal regimes.

121. See id. at 1151.

122. See La Porta et al., supra note 108, at 1149. Interestingly, the same group also has found that inferior government (measured by govermment intervention, public sector efficiency, public good 
I recognize the intuitive appeal of these studies, but it is important to note that they are based on extremely tenuous statistical data, a fact which in my view dramatically undercuts their conclusions. These studies are classical examples of "garbage in, garbage out." This is especially true of the conclusions drawn from statistical measures of legal institutions (e.g., efficiency of the judiciary, corruption and rule of law). ${ }^{123}$ At least one of the sources these studies cite has warned explicitly against attributing any exactitude to these numerical rankings: "Such calculations implicitly make a claim for Survey precision that it will not carry." 124 Moreover, all of these measures are based on pre-Asia crisis data. For example, the data for corruption and law and order-the most recent of the measures-are from the period 1982-95.125

The "law and order" measure from the International Country Risk Guide (ICRG) is a good example of problems in the data. This measure is calculated as follows: the ICRG staff assigns to each country a "law" rating from zero to three points and an "order" rating from zero to three points. ${ }^{126}$ The "law" rating is based on different criteria than the "order" rating. The "law" score is a subjective assessment of the "strength and

provision, size of government and political freedom) is associated with countries that are poor, close to the equator, ethnolinguistically heterogeneous, use French or socialist laws or have high proportions of Catholics or Muslims. See Raphael La Porta et al., The Quality of Government, 15 J.L. ECON. \& ORG. 222 (1999).

123. For example, one study used a measure of corporate governance developed by Flemings Research, an investment bank, which simply asked its country specialists to consider "the disclosure of information, transparency of ownership structures, management and special interest groups, adequacy of the legal system, whether the standards that are set are actually enforced, and if the boards of companies are independent and the rights of minority shareholders are upheld." See Simon Johnson et al., Corporate Governance in the Asian Financial Crisis, 1997-98, at 25 (unpublished working paper) (1999) (on file with author). These "specialists" ranked countries from 1 to 5 , with a 5 representing the United States and lower scores representing countries with fewer or poorer shareholder rights. The data were more recent than that used by La Porta et al., a fact that is both good and bad. On the one hand, the data should reflect any changes in shareholder rights arising from the Asian crisis. On the other hand, it should not be directly comparable to economic data from earlier years.

124. Raymond D. Gastil. Freedom in the World: Political Rights and Civil liberties 25 (1989) (noting also that the measures are "little more than a heuristic devise for printing maps or adding up doubtful totals" and that "[a]fter all, the dividing lines between the categories of the Survey are purely arbitrary points at which to cut into continua"). Nor does it seem that these imprecise measures are based on any more precise or reliable data. See id. at 26 ("[T] he Survey is based on library research, updated by a more or less continuous flow of publications across the author's desk.").

125. For example, the efficiency of the judicial system of a country was determined based on the estimates of the Business International Corporation from 1980 through 1983. See La Porta et al., supra note 120 , at 1124 .

126. See The Handbook of Country and Polmical Risk Analysis 185-200 (Llewellyn D. Howell ed., 2d ed. 1998). 
impartiality of the legal system." 127 The "order" score is a subjective assessment of the "popular observance of the law." 128 It is not surprising that one prominent legal scholar has described these measures as "crude." 129

Not only the methodology, but also the mathematical assumptions of these studies, are questionable. To account for the costs of the separation of ownership and control within firms, these studies include a mathematical function designed to represent the amount managers "steal" from shareholders. First, the model assumes that managers steal an amount, denoted $S$, of the firm's retained earnings. ${ }^{130}$ There is some chance that the manager will be caught stealing, so some amount must be subtracted from S. This amount to be subtracted should have at least two properties: (1) it should be lower in countries with poor corporate governance, where the manager is less likely to be caught and suffer damage from stealing; and (2) it should be lower as the value of $S$ increases, because the likelihood of being caught and suffering damage from stealing should increase as the amount the manager steals increases. The result is a "stealing manager" utility function that is quadratic and concave in S. ${ }^{131}$ My guess is that most managers would be surprised to find their behavior so specified (e.g., stealing multiplied by stealing), and probably would not agree with the specification. In any event, the authors of the studies do not attempt to justify their formulation.

Notwithstanding the flaws in these studies, the intuitive argument remains: if poor corporate governance is associated with market crashes, then one role of law is to improve corporate governance. Certainly the poor corporate governance explanation fits the state of the financial markets during the 1920s, prior to the Great Crash of 1929. At that time, there was a vast structure of holding companies and investment trusts,

127. Id. at 194.

128. See id. ICRG makes some effort to ensure that these scores are based on consistent criteria over time, although the description of these efforts is of something less than science. See id. at 189 ("To ensure consistency, both between countries and over time, points are assigned by ICRG editors on the basis of a series of pre-set questions for each risk component.").

129. See Scott, supra note 22 , at 11 .

130. The manager is assumed to derive utility $S$ from stealing $S$ from the shareholders.

131. The function given which satisfied these two properties is: $f(S)=S-\left(S^{2} / 2 k\right)$, where $k$ represents the (in)effectiveness of the governance regime (the higher the value of $k$, the weaker the country's corporate governance). See Johnson et al., supra note 123, at 7-8. This function is concave in $S$, i.e., as $S$ increases, the value of $S^{2}$ increases more; because this value is subtracted from $S$, the function $f(S)$ does not increase by as much as the value of $S$ increases. The value of $k$ will be larger than $S$. Specifying a denominator of $2 k$ rather than $k$ simplifies the result of the model after differentiation. 
and the holding companies controlled large segments of the utility, railroad and entertainment businesses. Moreover, there was evidence of poor credit allocation decisions due to an inadequate banking system, pressures associated with a large current account deficit and trade-related tensions, and substantial information asymmetry between issuers and investors. ${ }^{132}$ In such an environment, law may reduce the chance of a market crash by improving corporate governance.

\section{Family Ownership}

Another area, not recognized in existing scholarship, in which law may play a significant role in market crashes is in affecting the distribution of family ownership of firms. By preventing accumulation of large family-owned blocks of firms, law may make less likely the kind of investor cognitive error, moral hazard and information asymmetry that leads to crashes. Conversely, to the extent law supports concentration of family control at firms, law may have contributed to recent crashes.

This idea requires some explanation. Family control of large firms may be inefficient for two reasons. First, it may exacerbate the problems of market failure described in Part II. ${ }^{133}$ Controlling shareholders are more likely to prevent the flow of bad information to minority investors, and may be able to appropriate gains from such investors. As Shleifer and Vishny have argued, "as ownership gets beyond a certain point, the large owners gain nearly full control and prefer to use firms to generate private benefits of control that are not shared by minority shareholders." 134 Although a substantial portion of U.S. law recognizes this problem, and is devoted to the formulation of default rules designed to reduce the costs associated with such opportunistic behavior, the same is not true of law in many emerging markets.

Second, a related problem is that controlling shareholders are more likely to influence regulation, and therefore to perpetuate the types of market failure associated with crashes. Mandatory disclosure rules are unlikely to have teeth when the parties being forced to disclose also are the parties making the rules. Therefore, the ownership structure of corporate wealth may impede legal and regulatory development. ${ }^{135}$ If wealth is

132. See GaLBRATth, supra note 37 , at 178-82.

133. See discussion supra Part II.C.

134. Shleifer \& Vishny, supra note 116 , at 759.

135. In economic terms, the legal system can be described as "endogenous" to the control of the corporate sector. See Stign Claessens et al., Ultimate Controlling Owners of East Asian Corporations and Expropriation of Minority Shareholders, The First Annual World Bank Group-Brookings 
concentrated, and the owners can influence politicians, the legal system is not likely to evolve in a way that adequately protects minority shareholders. ${ }^{136}$ The legal system is unlikely to evolve to promote transparency and market-based activities until the ownership structure changes.

Statistics support these arguments. While ownership of large firms in the United States and Europe is distributed widely among investors, ${ }^{137}$ the same is not true in emerging markets. Outside of the United States and England, it is common for one large shareholder to own a firm. ${ }^{138}$ One recent study examined the ownership structure of 540 large corporations in 27 economies and found that most firms were not widely held, but rather were controlled by families or government entities. ${ }^{139}$ The concentrated ownership of firms in developing countries may be thought necessary because without adequate protection for minority shareholders, even large firms will need to have controlling shareholders in order to monitor managers. ${ }^{140}$ However, this chicken-egg problem is mooted where familymember controlling shareholders are the managers.

Two important statistical measures of share ownership provide valuable information about the level of corporate governance within a coun-

Institution Conference: Financial Markets and Development: Preventing Crises in Emerging Markets, at 18 (1999) (on file with the author).

136. This is especially true in those markets in which families control both the corporate and political arenas, such as the Marcos, Mobutu and Suharto families, and the "family" of Yeltsin and Berezovsky in Russia. See infra note 138.

137. To the extent ownership is concentrated, it is concentrated in investment vehicles (e.g., mutual funds) that do not control firms to the same extent as family owners/managers. Moreover, such investment vehicles are designed to hold diversified portfolios of financial assets, and any actions by them to participate actively in the management process tend to be counterproductive. See Thomas A. Smith, Institutions and Entrepreneurs in American Corporate Finance, 85 CAL. L. REv. 1,1 (1997).

138. See Stulz, supra note 114, at 24; Rafael La Porta et al., Corporate Ownership around the World, 54 J. FIN. 471, 491-505 (1999). For example, Russia's new "oliganchy" owns a controlling stake in major industries, including media. See David Remnick, The Black Box, NEw YORKER, Mar. 27,2000 , at 40,49 (comparing Boris Berezovsky, the owner of a large interest in the Russian state television network, Channel 1 or ORT, to the Morgan and Carnegie families). In many European economies, particularly Italy, family ownership is common, although in decline, and the effect of family control on shareholder value is mixed. See Lorenzo Stanghellini, Family and Governmentowned Firms in Italy: Some Reflections on an Alternative System of Corporate Governance, Univ. of Florence Working Paper (1999) (on file with the author). I am grateful to Alan Palmiter for this citation.

139. See La Porta et al., supra note 138, at 502 (describing common law countries as having more widely held firms than civil law countries).

140. See id. at 511. These findings cast doubt on arguments by Mark Roe and others that the wide dispersion in ownership of U.S. corporations is due to policies that discourage concentration under political pressure from corporate managers. See Mark J. RoE. Strong Managers, Weak Own. ers: The Political RoOts of american Corporate Finance 21-49 (1994). 
try. First, the percentage of equity that is external to the firm is a rough indicator of the level of corporate governance. This is because when the percentage of external ownership is high, there are likely to be additional pressures by these owners to monitor management. Moreover, in countries where the overall level of external ownership is high, there is likely to be pressure at the governmental level to create rules to protect external shareholders.

Second, the percentage of equity that is internal, or held by one or a small number of large shareholders, is likely to be a measure of poor corporate governance. In the United States, this number is very small, although it may not be fair for purposes of analyzing the Asia crisis to compare East Asian countries to the United States. A better benchmark is Japan. Japan is known to have large shareholder blocks and significant cross-ownership of shares, in part because of the influence of the "keiretsu" (groups of firms bound together by cross-ownership of shares and customer-supplier relationships). ${ }^{141}$ Nevertheless, the contrast between the level of external ownership in Japan and that in other countries in East Asia is dramatic.

Stign Claessens and Simeon Djankov, of the World Bank, and Larry H.P. Lang, of the University of Chicago, recently completed a study tracing and identifying the ultimate ownership structure of more than 2,500 corporations in several East Asian countries. ${ }^{142}$ The results are striking. In Indonesia and the Philippines, approximately $17 \%$ of the total market capitalization can be traced to a single family. ${ }^{143}$ The ten families with greatest share ownership in Indonesia, the Philippines and Thailand control half of the corporate sector, and the ten families with greatest share ownership in Hong Kong and Korea control about one-third of the corpo-

141. See Scott, supra note 22 , at 6 . In Japan, banks play the role of collecting and exercising the voting power spread among other shareholders, with varying degrees of success. See id. Unfortunately, previous studies of the keiretsu do not attempt to trace the ultimate owners of each company. See Claessens et al., supra note 135, at 3. One reason for Japan's diversified ownership may be the Occupied Forces policy following World War II to disperse ownership widely in Japan. See id. at 9.

142. See id. at 3. This study covered all ultimate shareholders who controlled over $10 \%, 20 \%$, $30 \%$, and $40 \%$ of the firm's votes. The $20 \%$ cut-off originally was suggested by Adolf Berle and Gardiner Means. See Adolf A. Berle, JR. \& Gardiner C. Means. The Modern Corporation and Private Property 93 (1932). Claessens et al. used the 20\% cut-off as their benchmark, and included the other cut-offs for comparative purposes. See Claessens et al., supra note 135, at 5-6. The ultimate owners are divided into five categories: families (including individuals), the state, widely held financial institutions (e.g., banks and insurance companies), widely held corporations, and miscellaneous (e.g., employee-stock ownership plans and cooperatives). See id. at 6.

143. These families were the Suharto and Marcos families, respectively. For example, the Suharto family in Indonesia controlled 417 listed and unlisted firms through business groups led by children, other relatives, and business partners. See Claessens et al., supra note 135, at 18. 
rate sector; in contrast, the level of family control in Japan is insignificant. ${ }^{144}$ The study also found that a higher concentration of control rights in a firm is negatively related to the firm's value, which suggests that a higher concentration in control rights leads to expropriation of minority shareholders. ${ }^{145}$

In addition, there are strong relationships between the share of the fifteen families with greatest share ownership in total market capitalization and three important measures of the quality of a country's legal system: the efficiency of the judicial system, the rule of law and corruption. ${ }^{146}$ To the extent the studies relying on such numerical measures are not flawed ${ }^{147}$ (or at least support some underlying intuition), the data support the conclusion that family ownership is correlated with poor legal protection. ${ }^{148}$ Consider the following table: ${ }^{149}$

144. See id. at 3.

145. See id. at 15.

146. See id. at 18-19.

147. See discussion supra Part III.A.2.

148. This, too, suggests a relationship between the development of the legal system and the structure of corporate ownership. These results have been confirmed in another recent study. See Johnson et al., supra note 123, at 25 (finding that efficiency of the judiciary, rule of law, and corruption predict changes in exchange rates better than standard macroeconomic measures, and that there is a positive correlation between having a better legal system and better stock market performance).

149. See Claessens et al., supra note 135, at 28, 35. "Family held" represents the percent of the total market capitalization that families control. "Widely held" represents the percent of the total market capitalization for which no single shareholder owns more than $20 \%$. The "efficiency of judiciary," "rule of law," and "corruption" measures are taken from La Porta et al., supra note 120, at 1142-43. 


$\begin{array}{cccccc}\text { Country } & \begin{array}{c}\text { \% Family } \\ \text { Held }\end{array} & \begin{array}{c}\text { \% Widely } \\ \text { Held }\end{array} & \begin{array}{c}\text { Efficiency } \\ \text { Of Judiciary }\end{array} & \text { Rule of Law } & \text { Comption } \\ \text { Japan } & 4.1 & 85.5 & 10.00 & 8.98 & 8.52 \\ \text { Malaysia } & 42.6 & 16.2 & 9.00 & 6.78 & 7.38 \\ \text { Thailand } & 45.5 & 28.0 & 3.25 & 6.25 & 5.18 \\ \text { Philippines } & 46.4 & 28.5 & 4.75 & 2.73 & 2.92 \\ \text { Indonesia } & 67.3 & 6.6 & 2.50 & 3.98 & 2.15\end{array}$

For these five Asian countries, a high percentage of family ownership (or a low percentage of widely held ownership) is correlated with weak legal protection.

In sum, law supports financial markets by encouraging trust among borrowers and lenders. To the extent markets fail, corporate governance measures attempt to reduce the costs of such failure, and to encourage the trust necessary for efficient markets. Where governance rules reflect the interests of non-controlling investors, such rules will help to prevent investor mania by narrowing information gaps. However, where governance rules reflect the interests of controlling family owners/managers, such rules will only perpetuate distrust and inefficiency. In the latter case, markets are more likely to crash, because minority investors are more likely to be duped and to face information asymmetries, and family owners/managers (and perhaps derivatively, other investors) are more likely to believe their investments are protected by explicit or implicit guarantees.

\section{B. A (Poor) Menu of Options}

There have been numerous recent proposals for regulatory reform of financial markets, especially emerging markets. ${ }^{150}$ Many are unrealistic;

150. See Adler, supra note 89, at 8-13; Gordon Brown, Toward a Strong World Financial System, WALL ST. J., Apr. 30, 1999, at A18 (advocating new international codes and standards and involving the private sector in crisis resolution); Paul Lewis, Corporate Conduct Code Is Proposed for Third World Nations, N.Y. TIMES, Apr. 29, 1999, at A7 (describing new code of good corporate con- 
most are deeply flawed. Various iterations of some proposals have been implemented. This section attempts to analyze and critique those reforms, grouped as follows: self-regulation, governance/architecture proposals, proposals to change capital controls and proposals related to expanding or changing the role of a lender of last resort.

\section{The Market and Self-Regulation}

If there is any majority view, it is the not particularly useful notion that markets are the best means of achieving price stability and equilibrium, and that the primary purpose of financial market regulation should be to correct for any market failure. ${ }^{151}$ It is important to note, as a starting point, that adequate protection against market crashes (i.e., against cognitive error, moral hazard and information asymmetry) does not necessarily require law. ${ }^{152}$ Well-functioning financial markets may offer the best protection at lowest cost, even in the absence of applicable legal rules.

Markets alone may reduce agency and information costs in at least three ways. First, managers of publicly held firms may be monitored when they raise capital. New investors have the opportunity to scrutinize managers, and managers with a reputation for appropriating shareholder wealth for themselves will not be able to raise funds to support expansion of the firm or new projects. ${ }^{153}$ To stem some investor concerns about their reputations, managers generally select one or more third-party intermediaries (typically investment banks and accounting firms) to assist with new issues. These intermediaries are willing to stake their reputational capital on their ability to evaluate a firm and its management, to

duct proposed by the Organization for Economic Cooperation and Development); Greenspan, supra note 53 (assessing how advances in technology and financial products affects financial crises); Robert E. Rubin, Strengthening the Architecture of the International Financial System, remarks to Brookings Institution (Apr. 14, 1998) <http://www.treas.gov/press/releases/pr2366.htm> (proposing better disclosure by emerging markets issuers to investors, enhanced surveillance of financial institutions, and mechanisms to avoid moral hazard in bailouts); Slimming the Bretton Woods Doo, EconomisT, Mar. 18, 2000, at 80 (describing report to Congress by Allan Meltzer and others suggesting limiting the roles of the IMF and World Bank).

151. See Crockett, supra note 8, at 22 ("The majority view is that free markets are the best guarantors of equilibrium in prices, and that official intervention should be limited to removing market imperfections, for example, by promoting the disclosure of relevant information and preventing the emergence of monopoly practices.").

152. It also is true that in a perfectly competitive market, with zero transaction costs, there would be neither information asymmetry nor agency cost conflicts, and therefore no need for corporate governance devices.

153. See Scott, supra note 22 , at 2. 
ensure that managers are not appropriating (too much) shareholder wealth. ${ }^{154}$ In addition, the investors in a firm may be large or active shareholders, who engage in such monitoring of management over time. ${ }^{155}$

Second, managers of publicly held firms who do not maximize shareholder value may not be managers for long. In the market for corporate control, new investors may buy a controlling block of the firm's shares and earn profits by replacing inefficient managers. Even if new investors do not take control of a firm, the fact that the market for corporate control exists creates incentives for managers to maximize shareholder value, because if they do not, their firm is likely to become a takeover target. In fact, in an efficient market for corporate control, there would be very few takeovers (just enough to persuade managers the possibility exists).

Third, managers of publicly held firms may choose to disclose information, even if they are not required to do so by law. Management would make such public disclosures, because if it did not it would face a higher cost of funds in the financial markets. ${ }^{156}$

In addition to solving investor-manager conflicts at individual firms, markets alone also may achieve the goals of law through private agreement among firms. Firms collectively may decide to enact and enforce rules on their own, outside of any formal legal regime. Such selfregulatory decisions may be regarded as efficient because they force parties to internalize the costs of self-regulated transactions.

The effectiveness of self-regulation has been mixed. ${ }^{157}$ Selfregulatory organizations tend to balance the interests of parties contending for economic rents, rather than to maximize efficiency. ${ }^{158}$ On the other hand, managers of financial institutions have strong incentives to monitor risks, and the most efficient forms of financial market regulation may need to rely on the financial markets and/or their institutions for as-

154. See Stulz, supra note 114, at 23.

155. See generally ROE, supra note 140.

156. See Easterbrook \& Fischel, supra note 100, at 675.

157. See, e.g., Partnoy, supra note 102, at 247-49 (criticizing self-regulation in the derivatives industry); Stephen Craig Pirrong, The Self-Regulation of Commodity Exchanges: The Case of Market Manipulation, 38 J.L. \& ECON. 141, 159-60 (1995) (criticizing self-regulation in the commodities industry).

158. See Sam Pelzman, Toward a More General Theory of Regulation, 19 J.L. \& ECoN. 211, 212 (1976); Richard A. Posner, Theories of Economic Regulation, 5 BELL J. ECON. \& MGMT. SCI. 335, 335-36 (1974); George J. Stigler, The Theory of Economic Regulation, 2 BELL J. Econ. \& Mgmt. Scl. 3, 3 (1971); Mancur Olson. The Logic of Collective Action: Public Goods and the THEORY OF GROUPS 5 (1965). 
sistance with the regulatory role..$^{159}$

\section{Global Architecture}

Although markets without law may work to reduce the risk and cost of crashes, markets often fail. Moreover, no country today relies solely on markets as the guarantor of financial stability, and regulators cannot point to specific rules that correct for market failure. ${ }^{160}$ Economists generally agree that markets function properly only within a well-defined legal and institutional framework, although there is debate about whether such institutions must be created by concerted action (which is really simply helping markets to work, and not inappropriate governmental intervention), ${ }^{161}$ or whether such institutions will develop spontaneously when the social costs of building them exceed their transactions costs. ${ }^{162}$

As to the three ways in which markets alone reduce agency and information costs, there are reasons to believe some form of governance nevertheless is needed. First, investment banks and accounting firms may not effectively perform their roles as third-party intermediaries. Although both institutions are potentially liable for negligence, there are reasons to believe these intermediaries do not suffer substantial losses in reputational capital even when they do not perform well. ${ }^{163}$ Also, large, active shareholders may either lack sufficient incentives to monitor management, or may use their stakes to obtain benefits for themselves only (and not for other shareholders). ${ }^{164}$

Second, if takeovers are costly, the threat of a takeover may not be sufficient to deter management from maximizing shareholder value. To illustrate this, assume that managers may select one of two options: Option

159. There is a great danger in delegating to private parties any market power in this regulatory role. See Partnoy, supra note 91, at 658-61 (describing negative consequences of reliance on credit rating agencies for regulatory purposes).

160. See Crockett, supra note 8, at 26 (citing academic support for this conclusion, and including the government of New Zealand as the only possible exception).

161. See, e.g., Barry Eichengreen \& Richard Portes. Crisis? What Crisis? Orderly WORKOUTS FOR SOVEREIGN DEBTORS 56 (1995).

162: See, e.g., Douglass C. North. Structure and Change on Economic History (1981); Harold Demsetz, Toward a Theory of Property Rights, 57 AM. ECON. Rev. 347 (1967).

163. There are few successful lawsuits against investment banks and accounting firms, in part because of the expenses associated with such litigation and in part because these entities may interpose a due diligence defense that issuers are not permitted. Moreover, there is reason to believe certain intermediaries develop market power and therefore do not lose reputational capital even when they perform their roles poorly. See Partnoy, supra note 91, at 634-35, 682.

164. See generally Smith, supra note 137 (arguing against such a monitoring role for institutional investors). 
A, which maximizes shareholder value, or Option $B$, which transfers $\$ 1$ million of shareholder value from shareholders to managers. If takeovers are not costly, and managers choose Option B, then new investors will buy shares of the firm, fire the managers, and reap the $\$ 1$ million gain (which would have been reflected in the cheaper cost of the shares they purchased). Therefore, managers will choose Option A. However, if the expenses associated with a takeover (e.g., fees for legal and financial services) are $\$ 2$ million, managers may choose Option $B$ without fear of a takeover, which would not be profitable for new investors. Other things equal, one would expect managers to engage in transactions that transfer wealth from shareholders to themselves of a value less than the cost of a takeover. Put another way, the cost of a takeover is a cap on (and perhaps a goal of) management bilking shareholders. Because takeovers are costly, the market for corporate control is likely to be less than perfect.

Third, there are reasons to believe managers of a publicly held corporation will not disclose negative information about the firm. ${ }^{165}$ For example, if disclosing bad news would both raise the firm's cost of capital and result in some personal cost to managers, ${ }^{166}$ they will not disclose. Moreover, even managers who decide to disclose information (positive or negative) in order to persuade investors to buy a new issue may not want to disclose information in the future, during periods when they are not seeking capital from the public markets. Of course, managers could attempt to bind themselves to making public disclosure continuously, but such binding is costly. In any event, without law, the financial market may underproduce information.

Therefore, the market's failure to reduce the costs of managershareholder conflicts creates the need for additional legal corporate governance mechanisms. There are two devices managers and shareholders typically use to reduce the costs associated with such conflicts: a board of directors to monitor management and limitations of management rights.

The board of directors monitors management, and can hire and fire managers. Because directors are elected by shareholders, it is believed that they will act in the interests of shareholders. Shareholders are able to replace managers who reward themselves with excessive perquisites or who are incompetent. However, for a publicly held firm, the shareholders typically are so dispersed that management may effectively determine the

165. See discussion supra Pan III.C.3.

166. Such personal cost might include direct compensation, loss of perquisites or even loss of a job. 
composition of the board. ${ }^{167}$ In such instances, it is unlikely that the board will play an effective monitoring role. ${ }^{168}$ Of course, a firm with a captive board may lack credibility when it seeks capital from the public markets, but in such cases it is the market and not the legal structure of the board that is doing the monitoring.

Law also may reduce manager-shareholder conflicts by limiting management rights. Law imposes on managers certain fiduciary duties to shareholders, including the duties of care and loyalty. ${ }^{169}$ As a corollary, law provides a mechanism to shareholders to enforce these limitations on managers, and therefore creates certain shareholder rights. ${ }^{170}$ However, open-ended fiduciary duty standards are effective only if enforced, which they may not be when family-managers influence enforcement.

These corporate governance structures, in sum, are the ones advocates of so-called "global architecture" proposals"171 seek to graft onto existing law in emerging markets. However, the most serious flaw in these proposals is that simply cutting and pasting U.S.-style law into an emerging market regulatory system will not work without experienced participants and credible enforcement. ${ }^{172}$

167. See Scott, supra note 22, at 2-3 (explaining role of boards as being different in theory and practice).

168. Even outside directors (those not involved in day-to-day management of the firm) are unlikely to be effective in monitoring inside managers. See id. at 7-8 ("But outside directors in my view cannot be typically expected to be more than a modest constraint on the behavior of those who put and keep them in office. For a firm in financial trouble, the board may sometimes be a device for managerial replacement short of bankruptcy proceedings. But neither the power nor the incentives of outside directors make them in general effective agents for minority shareholders, and imposing liability cannot fully compensate for the deficiency.").

169. The duty of care typically requires that managers act with ordinary diligence, care and skill; managers are liable only for gross negligence. The duty of loyalty typically requires that managers put shareholders' interests above their own, when the two conflict. Duty of care rules are rarely enforced, and often are described as more inspirational than mandatory. However, duty of loyalty rules-together with a credible mechanism to enforce violations of those rules-are critical to a corporate governance system. See id. at 6-7.

170. These rights include the right to sue for breaches of fiduciary duties and for violations of other laws imposing limitations on management.

171. See supra note 25 (listing the related proposals).

172. See Rubin, supra note 150 , at 4 ("Developing a strong financial system that is a match for the challenges of a global financial market is a long and difficult process. The institutions and laws we have in the United States to supervise our domestic financial system were developed over a period of a hundred years and must constantly be updated."). There is an old saw about the ground maintenance manager of a beautifully manicured natural grass football field who, when asked, gave the following advice to the builder of a new field: It's simple; just plant high quality seed in high quality soil and then water-every other day-for about a hundred years. The same advice applies to emerging markets seeking to adopt U.S.-style financial market regulation. 
Moreover, to some extent market forces act to increase competition in financial markets, and thereby put pressure on countries to improve corporate governance enforcement where such improvements are economically viable. Firms from countries with poor corporate governance rules may face a higher cost of capital than firms in countries with effective corporate governance rules.

Interestingly, to the extent corporate governance rules are important (because the financial markets alone cannot adequately reduce the costs of manager-shareholder conflicts), countries with a comparative advantage in such rules are likely to have firms with a lower cost of capital. On the other hand, if the market adequately addresses such conflicts, countries with strict corporate governance rules are not likely to have firms with a lower cost of capital.

The same arguments are true for sovereigns, too. Governments borrow in the capital markets. Their creditworthiness and therefore their cost of capital depends on the market's perception of the sovereign's ability and willingness to repay the borrowing. These factors depend not only on the macroeconomic environment, but on the quality of the underlying legal system. In this way globalization puts pressure on countries to improve their legal systems so that they and their firms can better participate in the capital markets. The dominance of market forces thus constrains the effectiveness of global architecture proposals. It is these forces that have led some legal scholars to suggest regulatory competition as a solution to the failure of existing corporate governance rules. ${ }^{173}$

\section{Capital Controls}

Many countries have proposed, or have in place, some form of controls on or rules governing the flow of capital. The proposals for controls include restrictions on capital inflows and outflows, currency boards, bank capital adequacy requirements and circuit breakers for exchanges. In my view, the common denominator of these proposals is not only that they seek, through regulation, to reduce the risk of financial crises, but also that they are both efficiency reducing and unfair.

First, consider restrictions on capital inflows and outflows. Restrictions on inflows are designed to reduce domestic dependence on foreign capital, and therefore to break the cycle of mania-panic-crash at the mania-panic stage, by deterring foreign investors with so-called "hot money" from shifting volatile funds into the domestic economy. Restric-

173. See infra Part II.C.1. 
tions on outflows are designed to break the cycle at the panic-crash stage, by preventing foreign investors from shifting funds out of the domestic economy.

Restrictions of inflows are more common and have limited support among economists. ${ }^{174}$ The best example of such a restriction is the capital inflow "tax" Chile imposed beginning in 1990. ${ }^{175}$ The "tax" was a required deposit on short-term capital inflows, so that its cost actually is loss of the use of these funds during the period of restriction. ${ }^{176}$ Such "taxes" or similar penalties are not prohibitions on capital inflows; rather, they are designed to deter some foreign short-term inflows to offset distortions resulting from a country relying excessively on short-term foreign borrowing. Thus, restrictions of inflows might offset other market failures, e.g., moral hazard resulting from a culture of implicit guarantees, which otherwise would lead foreign investors to overinvest in the country. As a result, some economists believe restrictions of inflows may enhance efficiency where there are distortions that encourage excessive foreign lending. ${ }^{177}$

Nevertheless, inflow controls, including Chile's, have been much criticized. A tax on short-term foreign inflows is especially costly to precisely the type of high-risk countries who may not be able to attract any long-term investment. For example, short-term lenders may believe the threat of not rolling over debt will deter managers from acting opportunistically. In this way, restrictions on inflows may prevent market participants from acting to reduce agency and information costs. ${ }^{178}$ Inflow controls also are inconsistent with financial liberalization, and are unlikely to be successful unless accompanied by strong domestic financial reforms and therefore bank reform. Finally, inflow controls create enormous incentives for parties to devise ways of avoiding the taxes, which leads to manipulation of the financial markets and no efficiency gains. ${ }^{179}$

174. See, e.g., Sebastian Edwards, Capital Controls Are Not the Reason for Chile's Success, WALl Sr. J., Apr. 3, 1998, at A19.

175. See Eichengreen, supra note 32, at 49-55. Columbia and Brazil have followed similar approaches. See id. at 50.

176. For example, a required deposit of $30 \%$ would impose an effective $\operatorname{tax}$ of $30 \% \times \mathrm{V} \times \mathrm{r}$, where $V=$ the value of the capital inflow and $r=$ the rate that the depositor would have earned in a comparable alternative investment.

177. See, e.g., EICHENGREEN, supra note 32, at 51.

178. See id. at $51 \mathrm{n} .25$.

179. Imports and exports may be used to evade the controls. For example, a foreign investor may purchase exports at an inflated price, and through a side agreement with the exporter eliminate risk associated with the export itself. The leftover funds are then invested in domestic securities without becoming subject to the inflow control. For a general description of the use of side agree- 
Outflow controls have virtually no support among economists, although several countries recently have considered them. Most notoriously, on September 1, 1998, Malaysian Prime Minister Mahathir Mohamad imposed foreign currency controls, preventing foreign shareholders from withdrawing money from Malaysia for one year. ${ }^{180}$

Some officials in emerging markets seem to like the idea of outflow controls as a way for them to regain control over monetary and fiscal policy, and then to inflate the economy through expansionary policies. They believe they are overly dependent on irrational foreign investors who panic whenever the government seeks to enact such expansionary policies.

However, even the strongest proponents of the cognitive error school will find it difficult to argue that foreign investors are acting irrationally if they withdraw funds when a government enacts inflationary policies. ${ }^{181}$ Rather, such investors are withdrawing because the government's economic policy is about to destroy the value of their investment. Moreover, outflow controls are even more costly to enforce than inflow controls. ${ }^{182}$ Finally, because outflow controls are imposed long after foreign investors have made the decision to invest in a country, they are not as effective in preventing the excessive risk-taking that inflow controls might prevent.

Another control, the currency board, is an attempt by a government to commit credibly not to follow the kind of inflationary policies discussed above. The currency board permits the government to issue local money only to match exactly its gold and hard currency reserves. A currency board would make inflationary policies impossible, because it would force a contraction in the money supply (and an increase in interest rates) following capital outflows. As of late 1998, currency boards were in operation in more than a dozen countries, including Argentina, Bulgaria and Estonia; the longest-running board is in Djibouti (forty-eight

ments and derivative securities to evade such regulation, see Partnoy, supra note 102.

180. See E. Han Kim, Globalization of Capital Markets and the Asian Financial Crisis, $11 \mathrm{~J}$. APPLIED CORP. FIN., Fall 1998, at 30. Ironically, Chile announced the same month that it was removing its controls in part because they had increased Chilean companies' cost of capital. See id.

181. Runaway inflation is the great enemy of foreign investors; relative price changes can quickly eat away any real gains from investment. Foreign investors perceive outflow controls as an admission by the government that they will not be able to resist inflationary policies.

182. Unlike inflow controls, outflow controls are imposed when investors are expecting large negative price changes (e.g., high inflation, devaluation), and therefore such controls create powerful incentives for evasion and an environment that encourages corruption and favoritism to government officials. See EICHENGREen, supra note 32, at 55. 
years). ${ }^{183}$

Although the effectiveness of currency boards has been mixed, it should be reasonably clear based on the analysis in Part II.C. 2 that currency boards will be able to prevent only a limited type of market failure: government moral hazard. The obvious problem with a currency board is how to ensure that the board does not exercise some influence over the money supply. ${ }^{184}$ To the extent markets crash because investors believe governments will devalue their currencies with the understanding that some supranational organization will come to the rescue, a credible currency board should correct this market failure. However, no one should expect a currency board to be a cure-all, because it cannot affect investors' cognitive error or information deficit.

Controls also may be imposed through bank capital adequacy requirements, which are designed to act at the bank level, rather than at the investor level. They are directed at various types of market failure, although the primary concern is moral hazard, which would lead banks and investors to take on excessive risks.

Rather than limit banks with heavy-handed regulation, regulators using such controls simply try to insure that banks have enough capital to support the risks they are taking. Banks engaged in riskier activities must have more risk-based capital. The primary source of guidance for such regulation is a voluntary set of standards suggested by the Basle Committee on Banking Supervision. ${ }^{185}$ The idea behind these standards is that they will more accurately reflect market practice.

However, these standards are seriously flawed. First, there is some evidence that heavy reliance on privately provided credit ratings leads to inaccuracies and creates enormous economic distortion. ${ }^{186}$ Credit ratings are less accurate than credit spreads and the standards neither distinguish among issues within a particular rating category nor among issues with different spreads. Credit ratings do not account for numerous risks, including market operational risks. The financial fiascos of the 1990s show that there are significant risks related to factors other than credit ratings.

Second, banks are able to use derivatives to add risk below the regulatory radar of the Basle Committee terms. In fact, the Basle-style rules

183. See Charles Enoch \& Anne-Marie Gulde, Are Currency Boands a Cure for All Monetary Problems?, Fin. \& DEv., Dec. 1998, at 40.

c 184. See By the Board, THE ECONOMIST, Sept. 5, 1998, at 72 (describing options to prevent such misbehavior).

185. See EICHENGREEN, supra note 32 , at $42-49$ (explaining role of such rules in preventing crises).

186. See Partnoy, supra note 91, at 623-24. 
create huge incentives for this type of "regulatory arbitrage" using derivatives. ${ }^{187}$

A third problem with Basle-style rules is that regulators and managers have different incentives. Regulators care (or should care) about systemic risk and preventing widespread failure of financial institutions. Managers are concerned about the volatility of earnings. The Basle rules rely on short-term measures of volatility that do not capture the risks of bank failure. ${ }^{188}$ Although such short-term measures of risk may impact the value of a particular bank's stock, because investors use it to generate a discount rate to apply to the institution's projected earnings, ${ }^{189}$ these measures are not appropriate for regulatory purposes. Regulators should not care about the volatility of earnings, except to the extent a bank with more volatile earnings also is more likely to fail (a conclusion that does not necessarily follow). ${ }^{190}$ If a bank is at risk of failing, it should not assuage regulators that its earnings are relatively constant. Conversely, if a bank is not at risk of failing, it should not be relevant to regulators that its earnings are volatile. ${ }^{191}$

The last type of capital control I will consider is the "circuit breaker." Circuit breakers are designed to prevent panics associated with investor cognitive error by controlling (usually by halting) capital flows following a large temporary decline on a specified securities exchange. Among the problems circuit breakers are intended to correct are problems occurring when large numbers of traders use the same model to assess the market. In such instances, supply and demand for financial instruments are inelastic, and a small move in prices may cause a crash. ${ }^{192}$

187. See Crockett, supra note 8 , at 30 (citing banks' use of credit derivatives 'to deliberately add risk to their portfolios").

188. See Martin Feldstein, Overview, in Maintaining Financial Stabiltty in a Global Economy, a Symposium Sponsored by tHe Federal Reserve Bank of Kansas City 319, 326-27 (1997).

189. Investors use various models to evaluate stocks. One such model, the Capital Asset Pricing Model, expresses the expected return of a stock as a function of the risk-free rate plus the product of the expected market premium times the stock's beta. The beta measure includes both the stock's covariance with the market and the overall volatility of the market. The key point for this article is that because investors based decisions on factors different from the factors regulators ideally should use, the incentives and behavior of managers and regulators will diverge.

190. See Feldstein, supra note 188, at 326-27.

191. A bank with more volatile earnings also is more likely to fail.

192. For example, in the U.S. stock market crash of October 1987, stock prices fell $31 \%$, or roughly $\$ 1$ trillion in value, during a four-day period on turnover of a mere $3 \%$. See Robert $\mathbf{R}$. Glauber, Systemic Problems in the Next Market Crash, 52 J. Fin. 1184, 1185 (1997). Most of the selling during this period was by portfolio insurers and mutual funds; for example, mutual fund redemptions on October 19, 1987, were between 1.5 and $2.0 \%$. See id. at 1187. 
To illustrate this, assume that U.S. stock mutual funds currently hold assets in aggregate of approximately $\$ 10$ trillion. Suppose that the market began dropping and that these funds faced redemptions of $2 \%$. Although the funds have some cash in their portfolios, they would need to liquidate securities both to pay investors and to maintain a constant stock-tocash weighting in their portfolios. Therefore, mutual funds facing redemptions of a mere $1 \%$ would need to sell $\$ 100$ billion of securities, or more than the entire average daily volume of the New York Stock Exchange. Circuit breakers are intended to halt trading before such sales cause an illiquidity crisis.

However, circuit breakers pose several problems, too. First, like all capital controls, they create incentives for evasion. Even when the circuit breakers are in force, securities may be traded on other exchanges or through over-the-counter contracts. Second, they widen the information gap between investors and market makers (and, to some extent, issuers). Individual investors typically will not be able to make the last trades before a circuit breaker is imposed, or the first trades after they are lifted. Nor will they be the first to learn about the imposition of the circuit breakers. Rational investors will realize that market makers and insiders will be more likely to profit during a time of crisis, and this realization will create uncertainty and may increase the cost of capital. Finally, circuit breakers may actually fuel panic. There is no empirical evidence supporting this point, but it seems equally plausible that investor cognitive error would increase more during the period in which the circuit breaker is in effect than it would have increased during a period of panic selling.

The above discussion does not exhaustively describe the opportunities to impose controls on the flow of capital to prevent crashes. There are other ways. The purpose of the discussion is to show that such controls are likely to create perverse incentives for investors and other inefficiencies. Consequently, they are unlikely to prevent, and may worsen, crashes.

\section{Lender of the Last Resort}

I address a new proposal for a lender of the last resort remedy in Part III.C. My objective here is simply to sketch an overview of the remedy.

From a theoretical perspective, the lender of the last resort is a simple idea with one simple problem. The idea is to create an institution that will be willing to lend as much as necessary during times of crisis or illi- 
quidity. ${ }^{193}$ The problem is moral hazard: if investors know the lender of the last resort will be there to bail them out in times of crises or illiquidity they are likely to take on excessive risk. The merits of a lender of last resort depend on whether the gains in alleviating investor panic are greater than the costs of increasing investor risk.

Unfortunately, in practice, the above theoretical calculus becomes more complicated. Lenders of the last resort may be domestic (the Federal Reserve) or international (the International Monetary Fund and the World Bank). They tend to be large, expensive and self-propagating institutions. They are inelastic, resistant to change and inherently undemocratic. They generally have been unwilling to lend unlimited amounts, so decisions must be made regarding how much to lend and where. Moreover, they often have imposed conditions on lending. Such conditions may actually increase the amount of market failure. For example, some commentators have argued that the International Monetary Fund worsened the recent crisis in Asia by pressuring countries to increase interest rates and close banks. Only then did the panic become a crisis, as foreign investors withdrew funds, corporations defaulted and there was a rush to the exits. ${ }^{194}$

Also, the presence of the IMF and the World Bank reduces the incentives for individual sovereigns to lend during times of crisis. These institutions are monopolistic and tend to be dominated by the United States, although other countries (especially Japan) have provided additional funds.

There are mechanisms to reduce the amount of moral hazard created by a lender of last resort. For example, the lender could institute a policy of "constructive ambiguity," in which it will have the right to intervene to save certain institutions, but will not promise to do so in the event of crisis. ${ }^{195}$ In other words, it may be efficient for the lender to follow an uncertain rule.

\section{New Alternatives}

If the current options and proposals are so poor, what can law do to prevent market crashes? Here is where legal scholars have much to con-

193. The objective is to support institutions that are solvent but temporarily illiquid. If funds were not made available, such institutions may need to liquidate assets simultaneously, and this liqvidation might result in an inefficient "rush to the exits."

194. See, e.g., Kristof \& WuDunn, supra note 84, at Al.

195. The term "constructive ambiguity" is attributed to Gerald Corrigan, former head of the Federal Reserve Bank of New York. See Crockett, supra note 8, at 28. 
tribute. The first step is to think about the available legal choices as products that can be bought and sold. In this section I build on this conception of law as product to analyze recent proposals to create a regime of regulatory competition. I add some new ideas to the proposals for regulatory choice and describe some limitations of current proposals. Finally, I describe how law could prevent crashes by diluting the controlling ownership of families.

\section{Law as a Product}

Law is a product, ${ }^{196}$ and like any product it can be bought, sold and traded. ${ }^{197}$ Calling law a product naturally has led to various proposals for creating markets in law, primarily in the corporate and securities context. ${ }^{198}$ However, scholars have not carefully analyzed the implications of thinking about law as a product.

The theory is that absent rules restricting international trade in legal rules, law-like any other product-can be bought, sold and traded in markets, both domestic and international, simply by having parties choose the applicable legal regime for a given transaction. As with other products, if Country $A$ has a comparative advantage over Country $B$ in production, both $\mathrm{A}$ and $\mathrm{B}$ can gain if $\mathrm{A}$ exports and $\mathrm{B}$ imports that product. If the same economic principles apply to the trade in law, then legal rules restricting international trade in law will, in aggregate, make all countries worse off. Conversely, allowing regulatory competition will make countries better off.

Moreover, if economists are correct that common law jurisdictions including the United States and Britain have a superior corporate and securities law product, ${ }^{199}$ then from an economic perspective other countries, including emerging markets, would be made better off by importing this product; at least until such countries improve their own corporate and securities law. On the other hand, if other countries, perhaps certain "regulatory havens" (e.g., Cayman Islands, Bahamas, Bermuda, Jersey), have superior regimes, then even U.S. and British issuers (and their in-

196. Roberta Romano has been the most prominent proponent of this view. See Romano, supra note 29.

197. Examples of decisions that can be characterized as buying, selling or trading law include individual parties deciding to include choice of law provisions in private contracts, corporations deciding to change the state of incorporation and individuals or institutions negotiating agreements resulting in legal protection or punishment (e.g., settlement agreements or plea bargains). In each of these examples, law is priced, just as any other product is priced in a private negotiation setting.

198. See infra Part III.C.2.

199. See supra notes $120-22$ and accompanying text. 
vestors) would be made better off by opting out of their inferior regime and into a superior one.

A closer analysis of these ideas requires a brief consideration of the demand for and supply of law. If law is a product it should have demand and supply functions. The purpose of this section is to explore, briefly, the implications of the supply-demand diagram for law.

First, what is the demand side of law? Potential consumers of law may include individuals and institutions. In general, consumers demand law when the benefits of the law exceed its costs. Consumers of a law should be willing to pay in aggregate for the utility they derive from its protection. However, as a particular type of law becomes more costly, consumers will demand less of it.

For example, consider a law requiring issuers to disclose material facts. Issuers may demand such a law if it helps them commit credibly to supplying material information to investors. If the costs of complying with such a law are not great, or if the law reduces the issuers' cost of capital, then issuers will demand more law (i.e., a stricter mandatory disclosure regime). On the other hand, if the costs of complying with such a law are onerous, or if the law increases the issuers' cost of capital, then issuers will demand less law (i.e., a more lax regime).

Investors, too, may demand such a law if it helps them to extract from issuers information they otherwise would not have learned, or could have learned only at high cost. If a mandatory disclosure regime does not raise issuers' cost of capital, and does not reduce investors' expected returns, investors should demand more law. If the regime is costly to both issuers and investors they should demand less.

Therefore, the relationship between the "amount" of law demanded and the price of law is a downwardly sloping function, as depicted in Figure 1. As the price of law increases, market participants demand less law. 
Figure 1 - Demand for Law

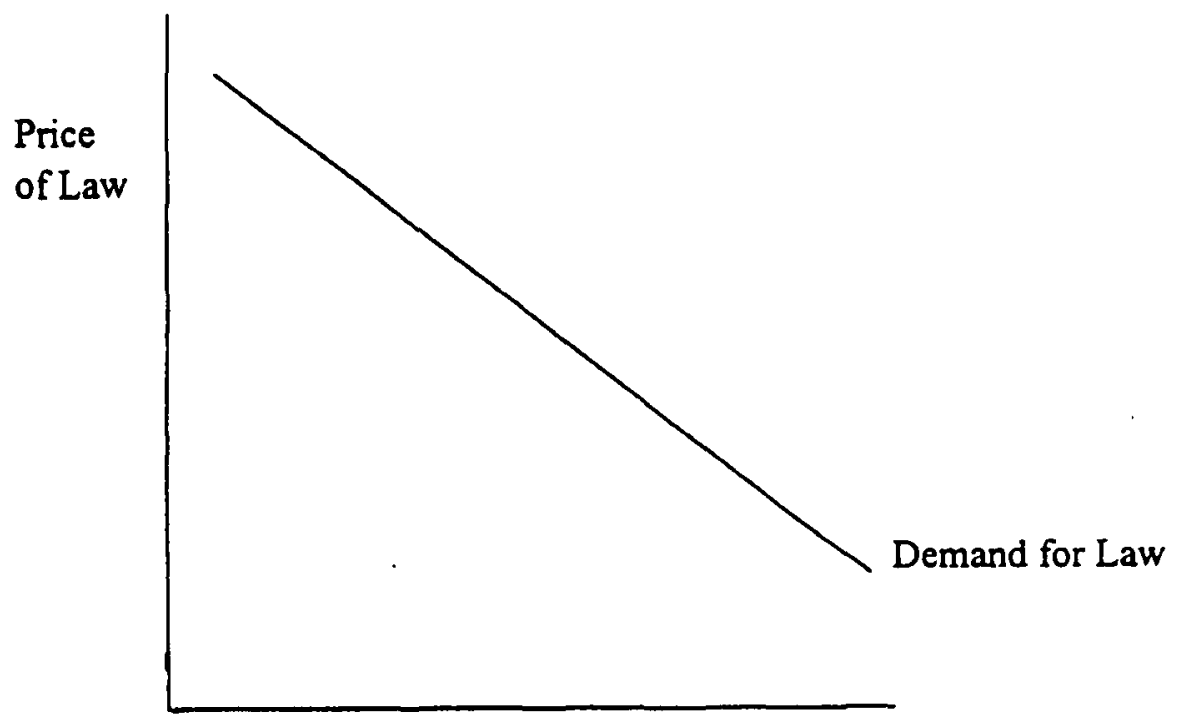

Amount of Law

Next, what is the supply side of law? Potential producers of law include regulators, private individuals and institutions who supply law to other individuals and institutions. An ideal regulator would enact laws whose benefits in aggregate exceed their costs. Unfortunately, regulators might not do so. ${ }^{200}$ If private parties are able to "capture" regulatory interests, then private parties (and, therefore, regulators) will supply law when the benefits to private parties exceed the law's costs.

Continuing with the mandatory disclosure example, an ideal regulator would require the level of disclosure that would equate public costs and benefits. Private parties would lobby regulators to require more or less disclosure depending on the net benefit to them. To the extent they were able to overcome collective action problems, investors might lobby

200. Unfortunately, the supply function of public regulators is difficult to specify, and may be based on economic or other factors. Regulators may seek to maximize power or prestige, or perhaps their department's annual budget. However, in general, regulators are willing to provide law when the benefits of the law to the regulator exceed the law's costs. 
regulators to increase the amount of disclosure. Likewise, issuers might lobby to reduce disclosure requirements. In general, as the net benefit to mandatory disclosure increased, more law would be supplied.

Therefore, the relationship between the "amount" of law supplied and the price of law is an upwardly sloping function, as depicted in Figure 2. As the net benefits from law increase, regulators and market participants supply more law.

Figure 2 - Supply of Law

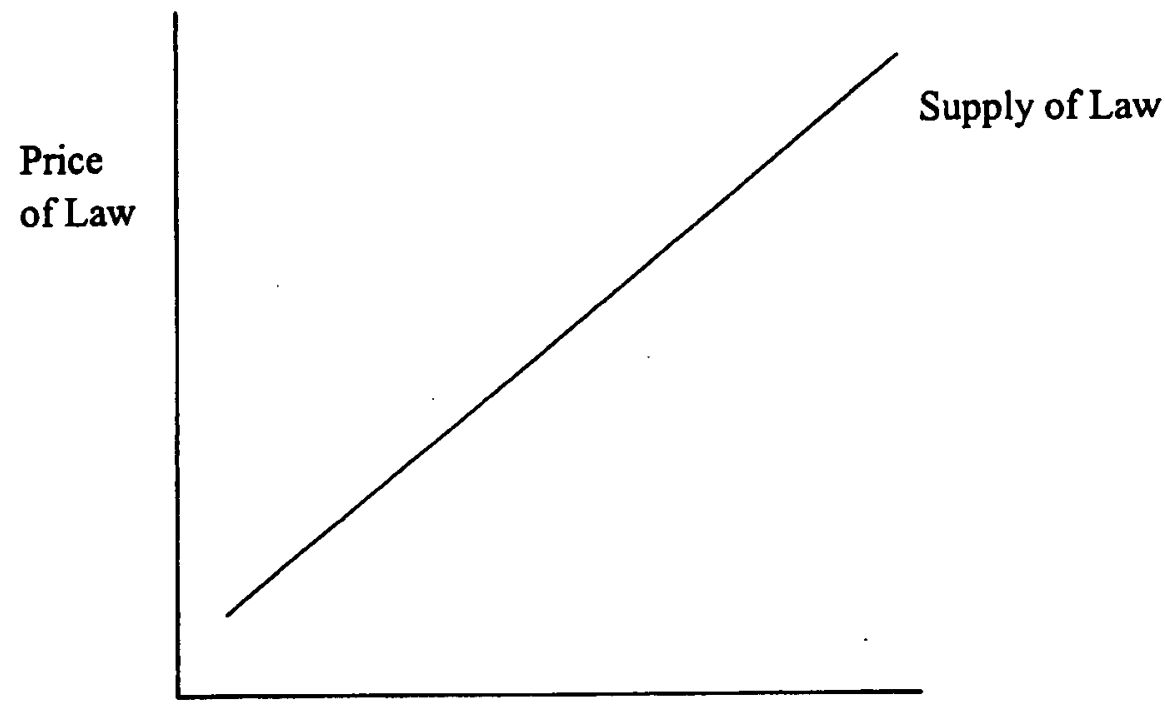

Amount of Law

Economic theory predicts that markets clear, and that demand equals supply at some price. At that price consumers demand and producers supply an optimal amount of law, as depicted in Figure 3. 
Figure 3 - A Market for Law as a Product

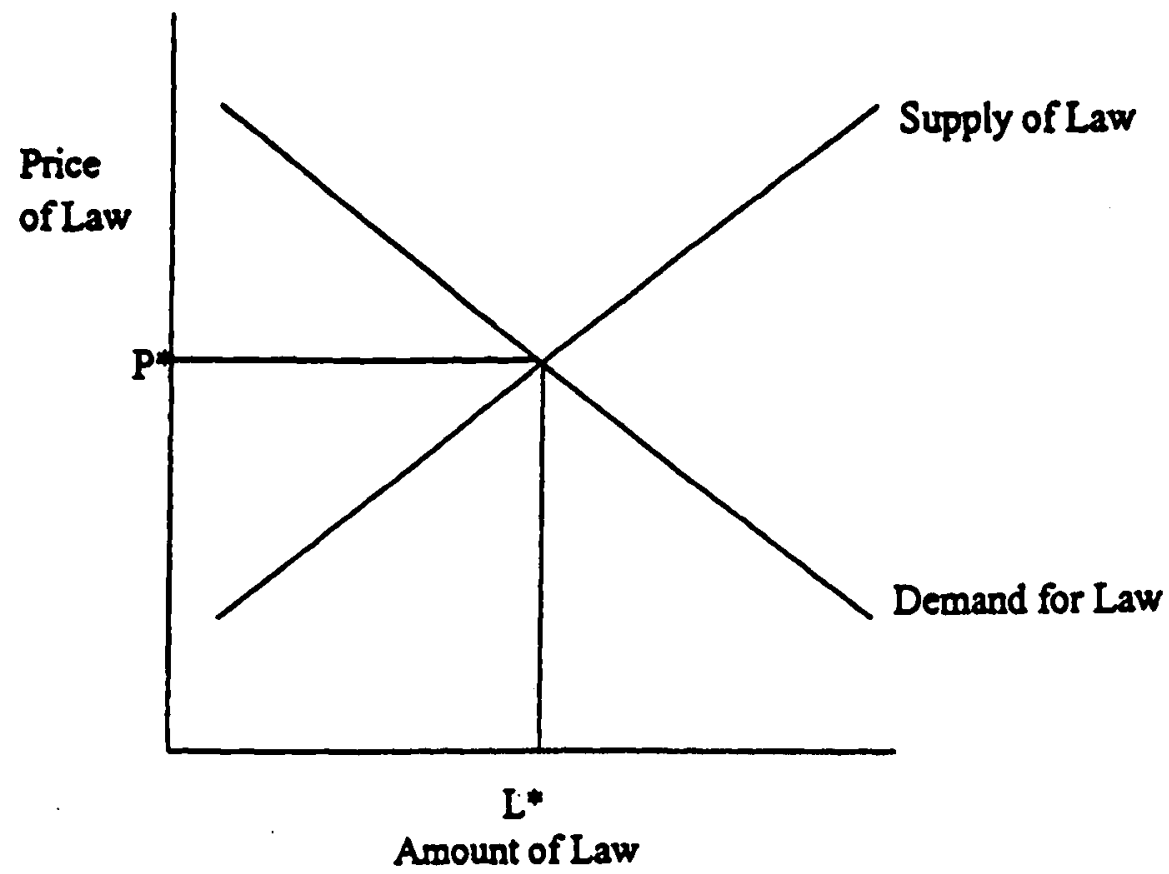

In Figure 3, $\mathrm{L}^{*}$ of law is demand and supplied at a price of $\mathrm{P}^{*} .{ }^{201}$

What does the above analysis add to the debate about regulatory competition (other than just another simple supply-demand diagram)? First, note that the analysis is consistent with the Coase Theorem, which specifies (under conditions of perfect competition and zero transaction costs) that "although the delimitation of rights is an essential prelude to market transactions .... the ultimate result (which maximizes the value of production) is independent of the legal decision." 202 Alternatively, in George Stigler's restatement of the Coase Theorem, "under perfect competition private and social costs will be equal." 203

At the equilibrium level of law $\left(\mathrm{L}^{*}, \mathrm{P}^{*}\right)$ in Figure 3, private and social costs are equal, the supply of law equals the demand for law, and parties do not need to bargain around legal rules. To the left of this equilibrium level, where the demand for law is greater than the supply of

201. These supply-demand diagrams are general equilibrium diagrams; in other words, they assume that all market participants have a role in establishing the levels of demand and supply.

202. R.H. Coase, The Federal Communications Commission, 2 J.L. \& EcoN. 1, 27 (1959).

203. George J. Stigler, The Theory of Price 113 (3d ed. 1966). 
law, demanders will pay suppliers to supply more law than is required. To the right of this equilibrium level, where the demand for law is less than the supply of law, suppliers will pay demanders so that suppliers may supply less law than is required. The point at which law is set (i.e., the delimitation of rights) is not relevant to the result; parties will simply bargain to reach the same efficient result regardless of the "amount" of law.

Now consider how the interpretation of Figure 3 changes once transaction costs are added to the analysis. ${ }^{204}$ If the initial placement of law is "sticky," because parties find it costly to bargain around the law, a suboptimal result is likely. For example, if the law requires too much disclosure, there may be efficiency losses because issuers are not able to persuade investors to allow them to avoid paying the regulatory costs associated with compliance. Likewise, if the law requires too little disclosure, there may be efficiency losses because investors are not able to pay issuers to disclose.

In this way, the above analysis of law as a product supports the recent arguments in favor of allowing regulatory competition in law. Regulatory competition allows parties to bargain around law at lower cost by simply selecting a different legal regime. If there is too much law in the parties' domicile, they may select a regime with less law, and vice versa.

On the other hand, the above analysis also indicates some difficulties associated with regulatory competition. Analysts evaluating stocks traded under different legal regimes must compare not only the "product" of the stocks (i.e., anticipated growth of earnings, discount rates, etc.), but also the "product" of their legal regime. If the legal regimes have different prices, the analyst must discount the value of the stock in the more costly regime.

Moreover, the "product" of law may be correlated with certain other real economic variables, making the analysis even more complex. ${ }^{205}$ One might expect that under such conditions, eventually one financial market regulator (or at least a small number of them) would dominate. ${ }^{206}$ Financial market regulation becomes more valuable as more investors and issuers are subject to it. ${ }^{207}$ Investors and securities analysts rely heav-

204. For an economic model of how transactions costs affect the divergence of private and social costs under similar circumstances, see Partnoy, supra note 102, at 239-42.

205. For example, growth of sales under one legal regime might be higher than in the other.

206. See Kamar, supra note 28, at 1950 (describing evolution of Delaware as the dominant state corporate law regulator). Of course, that regulator might then acquire market power, which would lead to anticompetitive behavior, e.g., its charging too high a price for law.

207. See id. (describing benefits to network externality effects, efficiencies, and economies of 
ily on comparative valuation in deciding what to buy and sell. It is much easier to compare two financial instruments when their issuers are subject to the same regulatory regime. Paradoxically, if law is a product, it may be a product that, because it is a natural monopoly, ${ }^{208}$ ultimately will fall under a single regulator once it is subject to regulatory competition.

\section{Choice in Law}

If law is a product, choice in law is important. ${ }^{209}$ In this section I use the notion of law as a product to analyze in greater detail the recent proposals for creating regulatory competition in financial markets by ena-

scale in having a single regulatory regime).

208. If law is a natural monopoly, it will have a cost function for which a single regulator would have lower total costs than two or more regulators.

209. Although the subject of choice in law is central here, it is a subject well beyond the scope of the article. However, it is worth noting that choice of law considerations have played a prominent role in the debate about regulatory competition, and the Supreme Court has endorsed the notion of regulatory choice in financial contracts. See Scherk v. Alberto-Culver Co., 417 U.S. 506 (1974). Scherk involved a contract between an U.S. corporation with extensive connections to the United States and a German citizen with corporations established in Germany and Liechtenstein, where the subject matter of the contract and its negotiations took place in a number of European countries and in the United States. See id. at 506. The Supreme Court stated that where the governing law is unclear

[s]uch uncertainty will almost inevitably exist with respect to any contract touching two or more countries, each with its own substantive laws and conflict-of-laws rules. A contractual provision specifying in advance the forum in which disputes shall be litigated and the law to be applied is, therefore, an almost indispensable precondition to achievement of the orderliness and predictability essential to any international business transaction ... .

Id. at 516; cf. Rodriguez de Quijas v. Shearson/American Express, Inc., 490 U.S. 477 (1989) (permitting arbitration of federal securities law claims based on contractual choice); Shearson/American Express, Inc. v. McMahon, 482 U.S. 220 (1987) (same).

Along similar lines, there have been attempts to export U.S. securities law by seeking to apply it extraterritorially in other countries. Cases involving such extraterritorial application of U.S. securities law have related both to allegedly fraudulent acts committed outside the United States but which have effects in the United States, and to allegedly fraudulent acts committed inside the United States which have effects abroad. See, e.g., Schoenbaum v. Firstbrook, 405 F.2d 200, 208 (2d Cir. 1968), modified on separate grounds and remanded, 405 F.2d 215 (2d Cir. 1968) (en banc) (section 10(b) applies to foreign transactions in securities of a foreign corporation when the transactions involve stock registered and listed on a national securities exchange and are detrimental to the interests of U.S. investors); see also Michael D. Mann \& Joseph G. Mari, Developments in Int'l Securities Law Enforcement and Regulation, 788 PLI/CORP. 7, 21 -52 (1992); Louise Corse, Section 1O(b) and Transnational Securities Fraud: A Legislative Proposal to Establish a Standard for Extraterritorial Subject Matter Jurisdiction, 23 GEo. WASH. J. INT'L L. \& EcoN. 573 (1989); John W. Hamlin, Exporting United States Law: Transactional Securities Fraud and Section 1O(b) of the Securities Exchange Act of 1934, 3 ConN. J. INT'L L. 373 (1988); Stephen Boatwright, Reversing the Expansive Trend of Extraterritorial Subject Matter Jurisdiction over Bad Conduct under Rule 10b-5 of the Securities Exchange Act of 1934, 23 TEX. INT'L L.J. 487 (1988). 
bling private parties to select their law of choice. I also suggest some new ideas for creating similar regulatory competition for public entities.

\section{a. Private Law Choice}

Several legal academics ${ }^{210}$ have proposed creating a regime of private law choice for financial market participants, under which issuers would be able to select the law of any participating country regardless of the physical location of the securities transaction. The legal regime selected would then "travel" along with the securities, and would apply regardless of where the transactions took place or (presumably) which investors were participating in trading. ${ }^{211}$ Among the stated advantages of this regime are:212 (1) increased range of investment choices for investors, (2) increased pressure on regulators to adopt efficient laws, (3) increased volume of securities transactions within those countries selected by issuers for regulatory purposes, ${ }^{213}$ (4) economies of scale as issuers choose to apply a given legal regime, and (5) elimination of any disadvantage U.S. firms face from onerous securities law requirements.

Legal scholars are beginning to debate whether these regulatory choice proposals are a good idea generally for corporate and securities law. Much of the scholarship in this area has focused on the effects of where a firm lists for trading purposes, a slightly different question than which law the firm selects to govern. ${ }^{214}$ My focus here is on the more

210. See, e.g., Romano, supra note 25, at 2365; Choi \& Guzman, supra note 25, at 907-08.

211. See Choi \& Guzman, supra note 25 , at 922.

212. See id. at 922-24.

213. Choi and Guzman assert that issuers selecting a particular country's regulatory regime are more likely to issue securities within that country (due to investor familiarity and ease of enforcement), and that therefore the volume of securities transactions within these selected countries would increase. See Choi \& Guzman, supra note 25, at 923 . It is unclear why Choi and Guzman's assertion about increased trading volume would be true. In a regulatory regime with true competition, investors might no longer care about familiarity. Moreover, the proposal for regulatory competition assumes that enforcement difficulties will be solved, thus eliminating another barrier to investors choosing a different regime. It is unclear, in any event, whether increased volume necessarily is good for a given regulatory regime. Finally, the assertion that trading volume will increase contradicts Choi and Guzman's point that differentiation in regulatory regimes will occur; differentiation necessarily places a cap on an individual country's volume. See id. at 934.

214. See, e.g., John C. Coffee, Jr., The Future as History: The Prospects for Global Convergence in Corporate Governance and Its Implications, The Center for Law and Economic Studies, Working Paper No. 144 (1999), Columbia University School of Law, New York, NY 10027 (analyzing how minority shareholders may benefit from a U.S. listing by a non-U.S. firm); Steven Huddard et al., Disclosure Requirements and Stock Exchange Listing Choice in an International Context (1998) (unpublished working paper, Duke University) (on file with author) (analyzing how competition among exchanges for listing affects disclosure requirements and concluding that the competition is a "race to the top"). 
modest question of whether regulatory choice makes crashes less likely. However, part of my answer is relevant to the general debate.

In particular, I believe there are two serious flaws in the regulatory choice proposals. First, financial markets already have achieved the proposals' advantages, with few exceptions. Second, to the extent financial markets do not allow for free choice, the barriers seem to be based more on transaction costs than on any anti-choice regulation. Next, I will explain these criticisms, and then offer an amended enforcement regime, which improves the proposals, at least as they relate to market crashes.

First, financial markets already have achieved the advantages of regulatory choice. With few exceptions, regulatory choice is the way of the world. This should not be surprising, based on the above analysis of law as a product. To the extent legal choices that minimize costs are available to market participants, they should be willing to choose them, and they should be able to execute them, given that transaction costs in highlyliquid financial markets are extremely low.

Just as the purchase of a risky bond may be viewed as the purchase of a risk-free bond plus the purchase of a guarantee, ${ }^{215}$ the purchase of a financial instrument in one country may be viewed as the purchase of a financial instrument without legal risk plus the purchase of a "legal risk guarantee." Put another way, if Country A has the optimal securities law regime for a particular investor, that investor's purchase of a financial instrument in Country A may be thought of as carrying zero legal risk. The difference between the price of the instrument under this optimal regime and the price of the same financial instrument under Country B's legal regime captures the legal risk premium associated with Country B.

An investor would choose a less viable legal regime only if the reduction in cost from moving from regime $A$ to regime $B$ exceeded the loss in expected additional protection associated with regime $A$. Why might investors face different costs under regime $B$ ? One reason might be that they are treated differently under B's legal system. This could be in two possible ways. One would be that there was a substantial reduction in cost in regime $B$ for this investor, as compared with other investors. The other is that the investor in B might not lose much expected additional protection, and in fact might gain some collateral benefit.

Unless there are barriers that prevent action, issuers will act to minimize their cost of capital and investors will act to maximize their expected return, given the risk. If a U.S. issuer can realize a cost savings

215. See Merton \& Bodie, supra note 87 , at 88 . 
by issuing outside the United States, it will do so. ${ }^{216}$ If such an issuance is regulated, the U.S. issuer will factor in the expected regulatory cost of the issuance. Assuming issuers are risk-neutral, ${ }^{217}$ they will violate the law if the expected benefit exceeds the expected cost. If the expected benefit is substantial, as it would be if there were gains to be made from switching legal regimes, and if either the probability of penalty from enforcement or the magnitude of such a penalty is low, then the issuer will issue the instrument anyway, even if there is a "technical" legal barrier. ${ }^{218}$ On the other hand, if there is a substantial, costly barrier, then issuers will stay within the relevant jurisdiction, because the expected cost of changing the legal regime exceeds the expected benefit. The relevant question, then, becomes not whether regulatory choice is a good idea, but to what extent is it already in practice, and most crucially, to the extent it is not in practice, are the barriers to such practice socially worthwhile?

Regulatory choice has been implemented largely through the growth

216. The following table describes the regulatory options currently available:

$\begin{array}{ccccc}\text { Issuer } & \text { Investor } & \text { Law Chosen } & \text { Trading } & \text { Law Applied } \\ \text { US } & \text { US } & \text { US } & \text { US } & \text { US } \\ \text { US } & \text { Non-US } & \text { US } & \text { US } & \text { Reg. S } \\ \text { US } & \text { US } & \text { US } & \text { Non-US } & \text { Offshore listing } \\ \text { US } & \text { Non-US } & \text { US } & \text { Non-US } & \text { Offshore listing } \\ \text { US } & \text { US } & \text { Non-US } & \text { US } & \text { Opt-out } \\ \text { US } & \text { Non-US } & \text { Non-US } & \text { US } & \text { Opt-out } \\ \text { US } & \text { US } & \text { Non-US } & \text { Non-US } & \text { Regulatory arb. } \\ \text { US } & \text { Non-US } & \text { Non-US } & \text { Non-US } & \text { Offshore issue }\end{array}$

The columns are, from left to right, the issuer's domicile, the investor's domicile, the law chosen to govern the transaction, the location of trading for the transaction, and the way in which the law is applied. The final column shows that U.S. law applies in the obvious case, in which only the United States is involved. Regulation $S$ refers to the U.S. regulation governing unregistered offers and sales made outside the United States. See Regulation S-Rules Governing Offers and Sales Made Outside the United States Without Registration Under the Securities Act of 1933, 17 C.F.R. $\$ \$ 230.901-.904$ (1996). Offshore listing refers to a United States issue listed on an exchange outside the U.S. Opt-out refers to attempts to select non-U.S. law despite substantial connections to the United States. Regulatory arb. refers to transactions with substantial connections to the United States that nevertheless are governed by some alternative law. See Partnoy, supra note 102, at 227-35. Offshore issue is an issuance to investors outside of the United States. All of these options are available to market participants, albeit at different costs and risk of enforcement.

217. This assumption probably is realistic. Although there are some reputational consequences to violating securities laws, a large number of companies are accused of such violations with some frequency.

218. In fact, the growth of the derivatives industry is evidence issuers have done precisely this, in response to regulatory costs. See infra text accompanying notes 219-21. 
in the derivatives ${ }^{219}$ markets, and in financial innovation generally. The derivatives market is now the largest market in the world, financial or otherwise. ${ }^{220}$ Why is it so large? A major reason is that in recent years derivatives and financial innovation have enabled financial market participants to engage in private regulatory choice. Just as participants may choose among various interest rates, indices and currencies for financial instruments, so may they choose among legal regimes. 221

The same is true of financial innovation generally. A U.S.-issued stock is a security regulated under U.S. law; an offshore equity swap with the same economic exposure is not. Insurance companies may not be permitted, under the relevant state law, to purchase Thai bahtdenominated bonds issued in Thailand; they may, however, purchase economically equivalent bonds issued by special purpose vehicles or trusts situated outside Thailand. Market participants today structure transactions to take advantage of differential costs in legal rules including tax, accounting, investment restrictions and government subsidies. ${ }^{222}$ These private law choices-precisely the type of choices being advocated by legal academics today-already have been made.

When put in these terms, financial innovation seems neither impressive, nor perhaps even a good idea. The ballyhoo about innovation in financial markets and financial market regulation is overdone. ${ }^{223}$ Since the 1970s finance scholars have uncovered new equations ${ }^{224}$ for assessing

219. Derivatives are financial instruments whose value is linked to, or derived from some other underlying financial instrument or index. For a description of the major classes and uses of derivatives, see Partnoy, supra note 102, at 216-26.

220. Although precise data are unavailable, the size of the market was estimated at $\$ 55$ trillion in 1996. See PARTNOY, supra note 21, at 15.

221. In fact, to the extent it is possible to arbitrage legal regimes, by buying a financial instrument in a "good" legal regime and selling an economically equivalent financial instrument in a "bad" one, there are no barriers to such opportunities today. Arbitrage in law may ultimately narrow the differences in legal regimes, just as arbitrage in economic variables narrows differences in prices in different locations. Put another way, the "Law of One Price" may apply to law, too.

222. See Partnoy, supra note 102, at 227-35.

223. Consider the following comment by John Kenneth Galbraith:

As to new financial instruments, however, experience establishes a firm rule, and on few economic matters is understanding more important and frequently, indeed, more slight. The rule is that financial operations do not lend themselves to innovation. What is recurrently so described and celebrated is, without exception, a small variation on an established design, one that owes its distinctive character to the aforementioned brevity of the financial memory. The world of finance hails the invention of the wheel over and over again, often in a slightly more unstable version. All financial innovation involves, in one form or another, the creation of debt secured in greater or less adequacy by real assets.

Galbraith, supra note 5, at 19.

224. These include the Black-Scholes options pricing model, Ito's lemma, and the Capital As- 
risk and expected return. Computer technology undeniably makes number crunching easier than it was in the early 1600s on the "Dam" (the outdoor space across from the Amsterdam town hall where exotic financial instruments were traded from 10 a.m. to noon daily). Moreover, financial market participants, particularly Wall Street investment banks, are creative in their packaging of new ideas. However, much of this "innovation" has simply involved reinventing the wheel, over and over, not to enhance efficiency, but to minimize regulatory costs.

The second flaw in regulatory choice proposals is that to the extent financial markets do not allow for free choice, the barriers seem to be based more on transaction costs than on any anti-choice regulation. In order to implement regulatory choice where it is not currently an option, countries would need to reduce these costs by making legislative changes to enable courts and/or arbitral tribunals to recognize and enforce claims by investors. The decision about whether and when to recognize and enforce foreign judgments is central to a nation's sovereignty. Changing such a decision is costly.

The governments of most emerging markets currently do not have reciprocity arrangements with the United States. For example, judgments cannot be enforced in most East Asian countries. Again, Malaysia and the Philippines are two examples. Because the United States does not have reciprocity arrangements with Malaysia, U.S. investors would need to rely on Malaysian common law to resolve disputes regarding recognition and enforcement of judgments in Malaysia (however, the United Kingdom, among other countries, has such reciprocity arrangements). ${ }^{225}$ In Indonesia, foreign court judgments generally are not enforceable, and foreign arbitration awards are enforceable only if reciprocity is deemed to exist. ${ }^{226}$ It is an open question as to which provisions of these enforcement requirements private parties may waive. ${ }^{227}$

Current issues of financial instruments reflect the absence of reciprocity arrangements. For example, according to prospectuses for Asian corporations offering securities in the United States, there are substantial

set Pricing Model.

225. See Foreign Judgments-Suppl. 1, Malaysia, at 3 (Apr. 1995). Malaysian law would govern whether a foreign court has jurisdiction in a case. See id. at 10. Arbitration awards are enforceable in Malaysia. Foreign Judgments-Suppl. 1, Malaysia, at 4.

226. Reciprocity exists when an arbitration award rendered in Indonesia is recognized and enforced in the court of the foreign country in question. See Foreign Judgements-Suppl. 3, Indonesia, at 4 (May 1996).

227. See Foreign Judgments-Suppl. 1, Malaysia, supra note 225, at 11; Foreign Judgements-Suppl. 3, Indonesia, supra note 226 , at 8 . 
risks that Singapore courts will not enter or enforce judgments. ${ }^{228}$ Nor will Singapore law protect shareholder rights. ${ }^{229}$

Elimination of these barriers would require, at a minimum, a treaty between country A and country B allowing issuers from A to opt into $B$ 's regulatory regime (or vice versa), and legislation in both $A$ and $B$ implementing the recognition and enforcement of judgments in the other country (i.e., reciprocity). It would be very costly for investors and issuers, even if it were in their interests, to persuade their regulators to reach these agreements.

The proponents of regulatory choice do not explain why existing barriers to choice may not be efficient. Such barriers may make investor cognitive error less likely by making investors wary about the risks of litigation in the country. Similarly, moral hazard is likely to be low if investors cannot even expect to be able to recover on favorable judgments. It seems odd, too, that East Asian countries would be able to reach such agreements with the United Kingdom, but not the United States, if the reasons are not related to high transactions costs.

Financial market participants are much more likely to be making regulatory choices based on taxes and accounting-related costs, whose differentials are likely to be significantly higher than, for example, the

228. One U.S. counsel has excerpted from the prospectus for a U.S. offering by a Singapore corporation the following statement describing advice given to the issuer: "The Company has been advised by its Singapore legal adviser . . . that judgments of U.S. courts, including judgments predicated upon the civil liability provisions of the federal securities laws of the United States, are not enforceable in Singapore courts and that there is doubt as to whether Singapore courts will enter judgments in original actions brought in Singapore courts predicated solely upon the civil liability provisions of the federal securities laws of the United States." Naoki Shimazaki, Asian Company Access to Funding in the U.S.; Key Legal Issues, presented at Lessons from the Asian Financial Crisis: Managing the Legal Fallout and Anticipating Future Crises, The State Bar of California Int'l Law Section, The Eleventh Annual Int'l Law Weekend, June 4-5, 1999, San Francisco, CA, at Al. Note that this is for a United States offering, not a foreign offering.

229. Consider the following disclosure, excerpted from the discussion of Risk Factors associated with the U.S. offering by a Singapore corporation:

The Company's corporate affairs are governed by its Articles of Association and by the laws governing corporations incorporated in Singapore. The rights of shareholders of the company and the responsibilities of members of the Company's Board of Directors under Singapore law are different and the responsibilities of members of the Company's Board of Directors under Singapore law are different from those applicable to a corporation incorporated in the United States, and, therefore, the shareholders of the Company may have more difficulty in protecting their interests in connection with actions by the management, members of the Company's Board of Directors or controlling shareholders of the Company than they would as shareholders of a corporation incorporated in the United States.

See id. at A2. Admittedly, disclosure of risk factors by a Singapore corporation offering securities in the United States, following the advice of U.S. counsel, is likely to reflect an abundance of caution. 
differential cost in mandatory disclosure between two regimes. However, regulatory choice proposals are addressed only to securities law, which, although it imposes very substantial costs in the United States, is unlikely to be a significant factor in most jurisdictions, especially compared to taxes.

Although a purely private regime of trading law might achieve the benefits of regulatory choice by avoiding the enforcement problem, proponents of regulatory choice oppose a purely private regime of trading law. They object that private contract terms must be negotiated and drafted by private parties, and that this process is too costly. They prefer regulations adopted and maintained by public regulatory bodies. They also object that issuers may be able to make a more credible commitment through public regulation than through private contracts. However, public law and criminal penalties may still apply to the conduct of private parties, even in a purely private regime of trading law. Moreover, reputational constraints and collateral may provide enforcement in a purely private regime. ${ }^{230}$ Such enforcement may be more effective than enforcement by a regime that has changed its laws only recently. Even countries adopting the letter of U.S.-style laws have not applied and enforced the laws in the same way they are applied and enforced in the United States. ${ }^{231}$

Finally, the regulatory choice proposals, even if they included an adequate enforcement regime, would not necessarily solve the market failure problems associated with crashes. In fact, the proposals could increase agency and information costs by creating additional investormanager conflicts related to the choice of legal regime. Managers would have incentives not to disclose changes in choice of law to current investors, or the existence of alternative legal regimes to new investors. Moreover, the proposals are not really for "free market" regimes. Ironically, those who believe markets alone perform an adequate role in reducing manager-shareholder conflict should not perceive a need to create competition among countries' regulatory systems. To the extent each country's market reduces these costs, this savings is optimal. Only those who be-

230. See discussion supra Part III.A.1.

231. See, e.g., Robert W. Hillman, Cross-Border Investment, Conflict of Laws, and the Privatization of Securities Law, 55 LAW \& ConTEMP. Probs. 331, 350 (1992).

Although section $10(b)$ itself may be mirrored in a number of foreign laws, judicial refinements of the section (for example, scienter and reliance standards, the implied private cause of action, and damage computation) and its application to private transactions are aspects of securities law that have, at least to date, not significantly influenced foreign law. Id. 
lieve markets fail to reduce manager-shareholder conflict should advocate the "free market" approach of enabling countries' regulatory regimes to compete. Certainly a market in which the vast majority of financial instruments were traded on a few "satellite" exchanges (e.g., New York, London and Tokyo) would achieve economies of scale and would not duplicate costs that a regulatory choice regime would impose. ${ }^{232}$

One possible solution to the problems of regulatory choice proposals is a bifurcated enforcement regime. Financial contracts would fall into two categories. The first category would be fully disclosed to the regulatory authorities and the public. Perhaps the terms of the contract could be posted on the Internet, so that both regulators and investors could assess the specifics of a particular transaction. The second category would not be disclosed, at the option of the parties to the contract. The consequence of nondisclosure would be that the terms of the contract would be unenforceable under the applicable law. For example, suppose a U.S. citizen invests in a U.S. firm using some financial contract as a vehicle. If the terms of that contract are not specified, and the required documentation is not delivered to regulators, then any claims under the contract (e.g., default) would be unenforceable under U.S. law. A U.S. court hearing a complaint by an investor about an issuer's refusal to honor the terms of the contract would simply dismiss the case.

Such a regime would create incentives for investors and issuers to bargain based on reputation and collateral (to the extent the secured party is in possession) - but not on law-to reach agreement for financial market transactions. To the extent parties do not want to disclose the terms of their dealings, they run the risk that the other party will not honor the contract. This enforcement regime forces parties to internalize the costs of nondisclosure. This proposal thus mimics the earliest financial markets, in which there was no applicable law, and novel transactions were simply unenforceable. ${ }^{233}$ Making such transactions unenforceable creates incentives for disclosure while allowing parties to transact outside the reach of law and public view, albeit with some additional cost and/or risk.

In conclusion, regulatory choice, to the extent it seems a good idea,

232. Of course, this may be one reason why investors and issuers prefer not to choose a large number of regulatory jurisdictions. There may be economies associated with having a large number of instruments traded on a small number of exchanges.

233. For example, during the 1600 s short sales of financial instruments were not enforceable (the rule was known as the "appeal to Frederick"). One leading commentator of the time believed this to be a fair and efficient rule for such transactions. See JOSEPH DE I.A VEGA. CONFUSIÓN DE CONFUSIONES 195 (1995). 
already has been put into practice. ${ }^{234}$ As a result, these proposals are unlikely to be better at preventing crashes than current market practice. If there are barriers to a regime of regulatory choice, the proponents of the theory do not explain how or why these barriers need to be overcome. If these barriers persist, and are inefficient, a purely private regime would seem to be superior to a regulatory choice regime.

\section{b. Public Law Choice}

There are, however, reasons why regulatory choice might be a good idea as applied to public borrowing and lending (i.e., by governments). The same arguments for regulatory choice apply in the public sphere, except that possibilities for self-regulation by private market participants no longer apply. The United States has overwhelming power to control the regulation of public and supranational entities, including the International Monetary Fund and the World Bank. There simply are no alternatives.

As a result, regulatory policy related to market crashes as applied to public entities has been disastrous. Take the Mexican bailout of 1994-95 as one example. It is replete with moral hazard and information asymmetry, all created or propagated by U.S. regulators. The Mexican "bailout" is often portrayed as a success. ${ }^{235}$ However, apart from the question of whether it was legal or constitutional for the United States to disburse billions of dollars of funds to another country using the Exchange Stabilization Fund, ${ }^{236}$ it cannot economically be regarded as anything other than a total failure.

The "success" of the bailout ignores the very low interest rate (approximately 5\%) charged to Mexico on its loans. Below-market interest rates are typical for lending in such situations, and create massive economic distortion and moral hazard.

Suppose, for example, that during a crisis Mexico promises to repay $\$ 20$ billion to the United States in five years with interest at a rate of

234. "On this basis, it should be noted that there today exists substantial scope for international (as opposed to federal) regulatory competition in the field of securities regulation . . . ." JoEL P. TRachtman, Regulatory Compettion and Regulatory Jurisdiction in INTERnational SeCURIties Regulation, Working Paper, Dec. 9, 1999, at 12 (on file with author).

235. In his 1997 State of the Union Address, President Clinton announced that U.S. residents should be proud of the effort to rescue our neighbor from its crisis, especially given that Mexico repaid the United States three years ahead of schedule, with a half-billion dollar profit to the United States. See William J. Clinton, Address Before a Joint Session of Congress on the State of the Union (Feb. 10, 1997). Of course, the repayment of interest on a loan should fairly be regarded as income, not profit; there was no gain on the loan.

236. See 31 U.S.C. $\$ 5302$ (1994) (stabilizing exchange rates and arrangements). 
$5 \%$, at a time when interest rates on Mexican government bonds are closer to $20 \%$. What amount should the United States give Mexico in exchange for this promise? Certainly not $\$ 20$ billion. The present value of the payments, valued at a $5 \%$ discount rate, would be $\$ 20$ billion. But that would be vastly overstating the value of Mexico's promise to repay. Instead, the value at the time of the promise, valued at a $20 \%$ discount rate, would be closer to $\$ 11$ billion. ${ }^{237}$

In other words, the United States by agreeing to exchange $\$ 20$ billion for Mexico's promise to repay, effectively made a gift to Mexico of $\$ 9$ billion in present value, an amount larger than the entire U.S. foreign aid program for all countries. In aggregate, the funds deployed to rescue Mexico, Thailand, Indonesia and South Korea, from 1995 to 1997 totaled almost $\$ 150$ billion. ${ }^{238}$ At below-market interest rates, these loans are extraordinarily expensive.

Importantly, the arguments for a lender of the last resort in Part III.B do not depend on the lender having monopoly power. There is no reason for the U.S. to exert such control in encouraging below-market lending. In place of the current regime, I suggest the following two-part proposal.

First, the United States and other countries would dramatically reduce (or eliminate) funding to the International Monetary Fund and the World Bank. These institutions serve many important roles, but lending at below-market interest rates following crashes is not one of them; this proposal depends on eliminating their role as a lender of the last resort.

Instead, the United States and other governments would announce a policy of competitive lending in the last resort. From the U.S. perspective, legislation could enable the United States to lend large amounts to any country it chose, provided the terms of the loans were disclosed and were made at rates substantially similar to those of existing instruments in the secondary market. Other countries could enact similar legislation.

For example, if Mexican interest rates ${ }^{239}$ were $20 \%$ during a crisis, the United States would be willing to lend any amount to Mexico at a

237. The present value of the retum of principal equals $\$ 20$ billion $/(1+0.20)^{5}=\$ 8.04$ billion; similarly, the present value of five-years of five percent interest payments $(\$ 20$ billion $\times 0.05=$ $\$ 1$ billion per year) is approximately $\$ 3$ billion. For a detailed description of the taxpayer costs associated with IMF lending, see Schwarcz, supra note 98, at 11-14.

238. See Michael M. Phillips, IMF Develops Plan for Speedy Bailouts, WALL ST. J., Dec. 10, 1997, at A2 (citing one economist calling these bailout packages a "quantum leap up in the moral hazard").

239. I am assuming that a country would use the relevant rate on a government bond with maturity comparable to that of the loan. 
rate of $20 \%$, but no less. Other countries also could lend, at competitive rates. The objective of U.S. lending would not be to earn a profit, as the United States claimed was a benefit to the Mexican bailout; rather, the U.S. lending would seek to be revenue neutral. If the United States was running a profit in its lending activities, then additional funds would be distributed; on the other hand, if the United States was incurring substantial losses, then it would raise the rates it charged borrowers or pressure defaulting borrowers to repay.

Such a regime would much more closely resemble a private financial market. Any country could lend at any rate, based on its relationship with the borrowing country and its expectations of that country's economic prospects.

The second part of the proposal is that the United States (and perhaps other countries with major securities exchanges) would commit formally to purchase stocks in the event of a substantial market downturn. In the past, the United States, through the Federal Reserve Bank, has acted as a lender of the last resort primarily in the bond and foreign exchange markets, but not in the stock markets. Instead, the Federal Reserve Bank has attempted to pressure market participants informally to lend funds to a particular investor, while acting in the government bond markets to ensure the money supply was expanding adequately. Why are government bond markets, but not stock markets, useful for these purposes?

Instead, I propose that in the event of a market crash the Federal Reserve would buy stocks, in some weighted market index (e.g., the S\&P 500). This proposal would eliminate the need for circuit breakers. Instead, if the market declined more than a certain percentage, the Federal Reserve would simply begin offering to buy S\&P 500 contracts at a price of, say, $20 \%$ below the opening market price. Thus, the Federal Reserve would act as an insurer, and would provide support for the market, with the goal of preventing investor panic. Other countries could enact similar policies.

This proposal would not create any moral hazard for investors in or managers of individual companies. Unlike the Long-Term Capital Management situation, any "bailout" would not be directed at any individual institution. Rather, the purchases would be directed at the market as a whole. Any investor who intended to buy and hold a diversified portfolio (e.g., the S\&P 500) would know she would never lose more than $20 \%$ during one day. She could always sell at a $20 \%$ one-day loss. 
To the extent this policy encouraged any kind of behavior, it would encourage investors to buy and hold diversified portfolios of stocks, precisely the strategy recommended by most financial theorists. This investment would create a larger pool of capital for U.S. corporations. At the same time, the existence of a "stock buyer of last resort" would help to calm investor panic. An investor worried about a particular day could simply submit a sell order, confident in the knowledge that the Federal Reserve would be willing and able to buy her stock at a floor price.

This policy might be expensive in the event of a substantial market downturn. The Federal Reserve could end up owning a lot of stock. ${ }^{240}$ But even in such an event, the government would be playing its proper role responding to a market crash, a role it likely would play even in the absence of a stock-buying policy. Today, in the event of a one-day decline of more than $20 \%$ in the stock market, the Federal Reserve likely would support the market indirectly, through purchases of government bonds. This proposal would not change the amount of support; it would only make it more direct.

Put another way, the policy would simply force U.S. taxpayers (who fund the Federal Reserve) in aggregate to pay to insure U.S. investors against a large one-day downward movement in their stock prices. It is the equivalent of U.S. taxpayers selling to shareholders a series of oneday put options, ${ }^{241}$ which investors might not be able ${ }^{242}$ (or willing) to buy otherwise. Regulators require all types of insurance. Why not require market crash insurance?

\section{Attacking the Family}

My last set of proposals relates to family control of firms. As discussed above, ${ }^{243}$ corporate law creates a set of default rules to protect minority shareholders from expropriation by majority shareholders. The goal is supported by both equity and efficiency rationales. On the continuum between closely-held and public corporations, corporate law rules attempt to define the point at which duties to minority shareholders are owed, and by whom.

240. Of course, the stock might later appreciate.

241. A put option on a stock index gives the owner of the option the right to sell the underlying stock index at a specified time and price.

242. Transaction costs for one-day put options would be expensive today, because such markets are not liquid.

243. See supra Part III.A.I. 
These rules are designed to mimic rules minority shareholders would have bargained for, in a world with low transaction costs. In reality, large and diffuse groups of minority shareholders face a collective action problem, and it would be extremely costly for them to meet, negotiate, and make decisions. Hence, corporate law duties provide a default rule to govern corporations and their managers.

One element missing from this story is the extent to which family structures influence the formation of corporate law, especially in emerging market countries where corporations have quite different ownership structures than their U.S. and British counterparts. The fact that corporate owners consist in significant part of family relatives greatly impacts the formation and enforcement of corporate law rules. It would be naive to expect a country to protect minority shareholder rights when the majority shareholders control not only the corporations, but the legislatures, too.

How can this problem be solved? Arguably, if investors know that corporations in a country may be controlled by one or more families, they will price this risk into their decision to invest as a minority shareholder. A rule protecting such investors might be justified under the transaction cost/collective action arguments above, but such a rule would be extremely unlikely to pass a family-controlled legislature. Therefore, investors who buy securities in a family-dominated emerging market should understand the risks of their investments.

On the one hand, countries that are able to attract capital despite the presence of family-controlled corporations and corporate law should be commended. On the other hand, their corporations probably are paying a higher cost of capital overall. Moreover, because the family control structure persists, there are information asymmetries and pressure for guarantees that lead to moral hazard. ${ }^{244}$ In other words, the same types of con-

244. To see more clearly the interaction of the parties and types of market failure, consider the following game scenario. Imagine a two-player game involving a foreign investor and a domestic family. The foreign investor can either (1) invest as a minority shareholder in the family's corporation, or (2) not invest. The domestic family can either (1) support a rule of law protecting all minority shareholders from expropriation of their interests, or (2) not support such a rule.

\begin{tabular}{|c|c|c|c|}
\hline & & Support & $\begin{array}{l}\text { Don't } \\
\text { Support }\end{array}$ \\
\hline Invester & Invest & 5,5 & $-10,10$ \\
\hline & Don't Invest & 0,5 & 0.0 \\
\hline
\end{tabular}

The investor chooses not to invest (and gains 0); the family chooses not to support the rule (and gains 0). This is a modified example of a prisoners' dilemma game. See, e.g., Douglas G. BAIRD ET 
ditions exist that existed during the decades of financial crises in the United States and Europe before the structures of regulation and ownership were changed.

Family ownership of firms is yet another reason why proposals to allow issuers to choose legal regimes are likely to be inefficient. First, it seems clear that family-controlled corporations can choose whatever legal regime they would like today. There are few barriers to them doing this, and even those barriers that do exist are unlikely to be enforced. Second, given these available options, most corporations nevertheless choose domestic law. The explanation for such choices must be that domestic law is the lowest-cost (or highest-gain) choice for such corporations. Third, even if these assumptions are incorrect, and there currently are barriers to these choices that could be removed, the fact that family-controlled corporations choose domestic law over another available choice (e.g., U.S. law) is strong evidence that they would choose a more lax regulatory regime than the domestic regime, if one exists (i.e., there would be a race to the bottom). Simply put, the proposals for regulatory choice in emerging markets are likely to be both impracticable, and-to the extent they could be implemented-inefficient.

To some extent, the market may correct these problems. Emerging markets investors are beginning to pay more attention to corporations infringing minority shareholder rights. Some minority shareholders are beginning to demand supermajority rules, which would guarantee minority shareholders a voice in discussions of major corporate decisions. ${ }^{245}$ There

al.. Game Theory and the LaW 33 (1994). Both parties would be made better off by cooperating (if the investor invests and the family supports a rule, they both gain); however, given the other party's preferences, each party will not make such a decision (e.g., from the investor's perspective, it should be clear that the family would be better off not supporting the rule regardless of its decision).

This result is not precisely what we observe in the real world of emerging markets investing. Instead, there are cycles: investors invest for a while until there is some crisis, at which point they pull out funds; then, years later, they begin investing again. The series of decisions to invest may be based on a variety of factors including pressure on institutional investors to invest abroad to achieve additional returns or diversification benefits. In particular, requirements (formal or informal) that institutional investors own a certain percentage of assets (e.g., based on some benchmark index of emerging markets) may lead investors to emerging markets following a period of brief calm. Another may simply be short memories. In any event, the cycles eventually end in crisis, with the result of the game described above: a legal environment hostile to minority shareholders, and an investment climate hostile to a country's corporations.

245. See David Swafford, Storming the Castle, 106 LATIN FIN. 16, 17 (1999) (citing as examples supermajority rights related to mergers, reorganizations, sale of assets, change of control, change of business, issuances of debt or equity, liquidation, adequate board representation, pre-emptive rights and rights of first refusal). According to prominent emerging markets fund manager Mark Mobius of Franklin Templeton, "Institutional shareholders are now asking for more transparency and better management since they have found that in many cases the disastrous losses could have been 
is pressure to change the practice of separating voting and non-voting shares, and then permitting foreign investors to buy and own only nonvoting shares. ${ }^{246}$ This multi-tiered approach resulted when family-owned companies first sought external finance, but were not willing to cede control.

Nevertheless, the legal regimes remain weak. ${ }^{247}$ As long as market failure persists, emerging markets countries will need a mechanism to help dilute family control of corporations. Only such dilution will spur the necessary reforms to entice investors. However, families are unwilling to make such reforms because they are able to expropriate gains under the current regime. Therefore, such a mechanism must make family owners better off (or at least maintain their current economic position) while diluting their ownership.

One idea is for the government simply to buy the families' interests and then sell those shares to the public. Unfortunately, such action would not necessarily result in any different ownership structure, because it would not remove the institutional forces creating the incentives for one family to control a corporation. A rule prohibiting such control would be inefficient; it often is beneficial to have a majority or controlling shareholder. Even if the only effect of the government purchases was to transmit ownership information to minority shareholders, such action would narrow the information gap and perhaps break the mania-panic-crash cycle.

Another idea is to give owners of a substantial stake in a publicly held corporation the choice of either (1) disclosing their interest or (2) losing their interest. For example, a rule could require the owner of ten percent or more of the stock ${ }^{248}$ to disclose ownership..$^{249}$ Failure to disclose ownership would trigger a "public poison pill" remedy. Any shareholder of a corporation could sue for dilution on behalf of the corporation for another shareholder's failure to disclose ownership of greater than 10\%. Upon proof of such ownership, the shareholder with more than $10 \%$ would be diluted down to a share of $10 \% .^{250}$ The rule likely

avoided with more transparency and better management." Id. at 17.

246. See id. at 18. In a typical example, one-third of the value of a company's equity is voting shares and two-thirds of the company's equity is non-voting shares. With such a structure, the owner of only one-sixth (and perhaps less) of the company (i.e., one-half of the voting shares) has control.

247. See supra Part III.A.

248. The requirement could apply to both voting and non-voting stock.

249. Obviously, ownership would include family members, relatives and other related beneficial ownership structures, including trusts and special corporations.

250. This could be either by redistributing the shares constituting ownership above $10 \%$ to the 
would never be used; its existence alone would create the incentive for shareholders to disclose large ownership stakes. The stock exchanges could then label these shares "subject to a controlling interest" 251 so that investors could easily see the corporation's ownership structure.

Ultimately, the market will need to be the disciplining force attacking family ownership of corporations and thereby encouraging minority shareholders to entrust managers over longer periods of time. ${ }^{252}$ Nevertheless, it is important to recognize that the ownership structure of corporations is just as important-if not more important-than other factors in explaining why emerging markets continue to crash. We should not expect supranational organizations, economists or even legal scholars to create a quick fix to this endemic problem. These markets require a basic level of trust. ${ }^{253}$ It took more than a century for the U.S. financial markets to develop the level of trust necessary to support diversified minority ownership of large public corporations. It will take emerging markets countries some time, too.

\section{An Application to the Asia Crisis}

Lastly, I will attempt to apply the above tools and analysis to answer a more specific question: What caused the recent crash in Asia and what could law have done about it?254 Much of the data supporting my conclusions is drawn from a detailed series of studies by the International Monetary Fund following the crisis in Asia. ${ }^{255}$

In my view, there were four primary causes. First, Asian institutions

other shareholders pro rata, or by issuing new shares to the other shareholders pro rata such that the greater-than-10\% shareholder would have its share diluted to $10 \%$. For example, for a company with 1,000 shares, 200 of which were owned by shareholder A, either (1) 100 of A's shares would be distributed to other shareholders, or (2) the corporation would issue an additional 1,000 shares to other shareholders, so that A's share would equal $10 \%$ (10\% of 2,000 shares is 200$)$.

251. Perhaps this could be done by adding a superscript " $c$ " for "controlling" to the stock's ticker symbol.

252. Some European markets are moving in this direction. See supra notes 137.38 and accompanying text.

253. See supra Pan III.A.1.

254. Although this analysis applies to the recent crises in Asia, similar analysis could be applied to other recent crises, including for example the recent crisis following the devaluation of the Mexican peso in December 1994. For a comparison of the Mexican crisis of 1994-95 with the more recent crises in East Asia, see Sebastian Edwards, On Crisis Prevention: Lessons from Mexico and East Asia, in The First annual World Bank Group-Brookings InstTtution Conference: FinanCial. Markets and Development: Preventing Crises in Emerging Markets, Mar. 26-27, 1999 (on file with the author).

255. See ADAMS ET AL., supra note 55, at 11,15 . 
(especially banks) ${ }^{256}$ and offshore investors borrowed excessively in U.S. dollars for short maturities, often without the knowledge of regulators or other market participants. ${ }^{257}$ Second, the foreign exchange regimes of several Asian countries (first and foremost, Thailand) became increasingly vulnerable to capital flows, due to the large capital inflows during the mid-1990s, large current account deficits in 1996 and depletion of foreign currency reserves in late 1996 and early 1997. Third, and in my view most important, the first two causes were hidden from view, due primarily to the lack of transparency associated with both public and private investment portfolios (and especially in derivatives). ${ }^{258}$ Fourth, legal structures that have prevented or eased the effects of crises in individual countries either were not present or did not work in Asia. ${ }^{259}$

The key to the crisis was Thailand, although many of the events in Thailand were repeated later in other countries. During the 1990s, the Thai baht was a managed currency, meaning that the Bank of Thailand intervened to keep the baht within a certain range. When the central bank of a country does not allow supply and demand for its currency to determine its price (i.e., the foreign exchange rate) under a so-called floating rate regime, it is inevitable that there will be downward or upward pressure on the domestic currency. When the demand for domestic currency is less than its supply - as is the case when a country has a current account deficit (which Thailand did during 1997) - there is downward pres-

256. The largest swing in capital flows in the affected countries in Asia was in bank lending flows. There was considerable unrecorded capital flight from Asia, originating with both individual and corporate domestic residents. One major difference between the Mexican crisis and the Asia crisis was the nature of the capital flow reversals. Inflows into Mexico were predominantly portfolio flows; inflows into Asia were predominantly bank lending flows. Likewise, the reversals in Mexico . were portfolio flows; the reversals in Asia were bank flows. See id.

257. By 1997, international banks had outstanding loans in Indonesia, the Republic of Korea, Malaysia, the Philippines and Thailand of $\$ 275$ billion, of which the majority was short-term. See Sachs, supra note 13 , at 13.

258. One major study concludes that corporate governance was "more important than macroeconomic conditions or policy responses in determining the extent of exchange rate depreciation and stock market performance across countries." Johnson et al., supra note 123, at 53. This study also found that the extent of enforceable rights for minority shareholders "appears to have been of first-order importance in determining which countries experienced relatively minor and which experienced very large depreciations in their exchange rates." Id.

259. Jeffrey Sachs has cited the absence of three such legal structures: (1) there was no lender of the last resort to satisfy the withdrawals of skittish international banks and investors, (2) there was no international deposit insurance to persuade depositors that they did not need to withdraw simply because other depositors were withdrawing, and (3) there was no bankruptcy law to foster collective action among creditors and to prevent a "creditor grab race." Sachs, supra note 13, at 13, 14. According to Sachs, these legal structures have worked in developed countries to prevent the types of collective action problems, which historically led to panics. 
sure on the domestic currency. If the currency is not allowed to depreciate, because it is being managed, then the central bank must expend reserves to satisfy counterparties who want to buy U.S. dollars and sell baht.

During this same period, there was a rapid increase in foreign investment in East Asia, corresponding to the "mania" stage. The boom in bank inflows into Asia began as early as 1991 with the "carry trade," which started in Malaysia. Banks began lending in Malaysian currency, while borrowing in some other currency (typically U.S. dollars) to take advantage of high Malaysian domestic interest rates. Similar trades began in Thailand and Indonesia in 1993. Asian central banks had engineered high domestic interest rates to battle inflation while maintaining exchange rate stability. Without high interest rates, capital flows would not have been as strong and there would have been downward pressure on the Asian currencies.

Many of these carry trades were unregulated, not publicly disclosed and often not reported on institutions' balance sheets. ${ }^{260}$ No legal infrastructure supported these transactions and regulators were not monitoring or tabulating such trades. As a result, there was great uncertainty about official debt statistics, especially statistics related to domestic corporate debt to foreigners. Foreign exchange transactions shifted offshore, again outside official monitoring and statistics, especially to Singapore and Hong Kong, where the baht, rupiah and ringgit were traded. ${ }^{261}$ For example, U.S. dollar-Malaysian ringgit trading rose from \$25 million in 1992 to $\$ 9.5$ billion in 1995 ; average daily volumes increased by an estimated four hundred fold during this time. ${ }^{262}$ Throughout this period, the amount of credit to firms increased dramatically. ${ }^{263}$

The first downward pressure on the Thai baht occurred in July 1996, when the Bangkok Bank of Commerce, a major private bank, collapsed and the Bank of Thailand injected liquidity to support the system. ${ }^{264}$ During January 1997, concerns spread about non-performing assets in Thailand's financial sector, including property loans that were in or near default. ${ }^{265}$ During the next several months, hedge funds took short positions

260. For example, during 1996 market participants in Indonesia and Thailand used backs of envelopes and postdated checks as commercial paper. See ADAMS ET AL, supra note 55, at 41.

261. See id. at 42 .

262. See id. at 43.

263. See infra notes 284-89 and accompanying text.

264. See ADAMS ET AL., supra note 55, at 44 . A central bank "injects liquidity" by increasing the money supply, either by lowering interest rates or by buying outstanding govemment bonds.

265. For example, Somprasong Land, a large finance company heavily exposed to the property 
on the baht, betting that it would collapse. ${ }^{266}$

In May 1997, reports circulated throughout Thailand that large Thai corporations were beginning to sell baht and buy U.S. dollars, perhaps because of concern that they would not be able to satisfy their U.S. dollar liabilities unless they had currency on hand. ${ }^{267}$ To support its currency, the Bank of Thailand entered into forward contracts to sell U.S. dollars and buy baht. ${ }^{268}$ On two days alone-May 8 and 9-the Bank sold forward contracts of $\$ 6$ billion, roughly one-fifth of its net foreign currency reserves. ${ }^{269}$ At its peak, the Bank of Thailand was obligated to deliver an estimated $\$ 26$ billion-roughly the amount of remaining net foreign currency reserves-on its forward contracts with various counterparties. ${ }^{270}$ The Bank's defense of its currency thus appeared to be unsustainable. ${ }^{271}$ On May 15, the Bank essentially admitted this inevitable fact by imposing capital controls on foreign currency and by increasing domestic interest rates. ${ }^{272}$

At this point, investors were in the "panic" stage; they should have concluded that a devaluation of the baht was inevitable. Unfortunately, investors had poor information regarding the borrowings of Thai firms (and the Bank of Thailand), a problem legal rules might have prevented. The Bank of Thailand floated the baht on July 2, and it immediately devalued $15 \% .{ }^{273}$ Investors increased the pace at which they were with-

sector, failed to make a foreign debt payment on February 5, 1997. See id. at 45.

266. See id.

267. See id. at 46.

268. A forward currency contract is an agreement to exchange one currency for another at a specified date and rate. This rate-called a "forward" rate-is quoted as a premium over or as a discount from the current (i.e., spot) currency rate and is determined by the difference between interest rates in the two currencies. Instead of selling currency on a forward basis, the Bank of Thailand could have allowed interest rates to rise until the supply of and demand for currency reached equilibrium. However, the Bank of Thailand did not increase interest rates until May 15, 1997. See id.

269. See id.

270. These counterparties included offshore hedge funds $(\$ 7$ billion), other offshore counterparties ( $\$ 8$ billion), onshore foreign banks ( $\$ 9$ billion), and onshore domestic banks ( $\$ 2$ billion), although it is possible a significant portion of the onshore contracts were executed on behalf of offshore hedge funds. See id.

271. This perception seems to be justified. The forward contracts which obligated the Bank of Thailand to deliver U.S. dollars in the future in exchange for baht represented a claim on its foreign currency reserves. The Bank had entered into $\$ 26$ billion of contracts, which represented claims on all of its foreign currency reserves. See id. It had no additional reserves remaining to support additional forward contracts.

272. See id.

273. See id. at 49. Because of capital controls imposed in May, the onshore and offshore markets were segmented. The baht declined even more-approximately $20 \%$-in offshore markets, where the panic appeared to be even greater. See id. 
drawing funds from the Thai markets, which declined markedly. ${ }^{274}$ This was the final stage: crash.

Other countries in Asia had been following similar foreign exchange policies, and they quickly suffered similar fates. The Central Bank of the Philippines and Bank Indonesia floated their currencies on July 11.275 As with Thailand, domestic and foreign investors in the Philippines and Indonesia had been betting against the depreciation of these currencies, using currency swaps, options, and other off-balance sheet transactions that went largely unreported. ${ }^{276}$ Bank Negara Malaysia, the central bank of Malaysia, stopped defending its currency, the ringgit, in July, and imposed trading restrictions and controls in August. ${ }^{277}$ Emerging markets finance essentially shut down following the Asia crisis in $1997,{ }^{278}$ although the financial panic had subsided within a year. ${ }^{279}$

Although a complete review of East Asian legal systems is beyond the scope of this article, it is worth examining a few examples from the markets in Thailand and Indonesia, two countries hit hardest by the crisis: Professor Kenneth Scott has compiled quantitative and qualitative measures of the corporate governance regimes in several countries, including these two. He finds, for example, that although both countries have duty of care and duty of loyalty rules, the rules lack teeth and are not enforced. ${ }^{280}$ There is little evidence that boards of directors are effec-

274. It is worth noting that the credit rating agencies, which many laud as accurate raters of sovereign risk, not only did not foresee this problem, but did not even recognize it until months later. Neither the speculative attack on the Thai baht in May 1997, nor the floating of the baht on July 2, 1997, had any effect on Thailand's sovereign debt ratings. For example, Standard and Poor's did not even put Thailand on its credit watch until August, and did not downgrade Thailand's sovereign debt rating until late October 1997 . The rating agencies were similarly sluggish in Indonesia and Korea. See id. at 49, 52-53.

275. The Philippine peso had been floating within a range; that range was widened on July 11. Similarly, the Indonesia rupiah had been trading within a band of $8 \%$; that band was widened to 12\% on July 11 (Indonesia abandoned the band entirely on August 14, 1997. See id. at 49.

276. See id. at 48.

277. See id. at 49.

278. See The Bankers Take Cover. THE EConomist, Sept. 19, 1998, at 87.

279. See The Darkest Hour Comes Just Before Dawn, THE Economist, Oct. 17, 1998, at 85 (describing lower interest rates and stable currencies throughout East Asia).

280. A Thai shareholder owning $5 \%$ or more of a listed company's shares may sue a director in a derivative action on behalf of the company if the director action is not "in good faith and with care to preserve the interests of the company;" however, self-dealing transactions are valid if accepted by the board of directors, without reference to any standard of fairness. See Scott, supra note 22 , at 16. Because Thai courts are slow, and few shareholders have brought cases involving director liability, even the existing laws have little meaning and directors do not have comprehensive fiduciary duties. See id. Indonesia's requirement that directors "act in good faith and with a full sense of responsibility towards the company" is recent; before 1996, directors were not even considered fidu- 
tive in monitoring managers. ${ }^{281}$ Thailand and Indonesia also have very poor shareholder rights protection and legal enforcement. ${ }^{282}$

In general, legal rules did not protect investors during this crisis. There was not a well developed market for corporate control in Asia, so managers who did not perform well did not face removal. Moreover, shareholders of East Asian firms generally cannot sue on behalf of the firm. ${ }^{283}$ Without a private right of action, and given the level of family control, minority shareholders had little hope that existing securities laws would be enforced.

Absent legal rules constraining managers, there was a rapid increase in leverage at Asian firms during the 1990 s. $^{284}$ At the same time, the av-

ciaries and had no obligation to act in the shareholders' interest. See id. at 13. However, the new law lacks implementing regulations, and government enforcement bodies lack authority to bring actions against directors. See id. On the other hand, Thailand has implemented rather strict tender offer rules, although it is unclear what their effect has been. For example, the acquirer of more than $5 \%$ of the stock of a listed company must file a report the following day, and under Thai law, the acquirer of $25 \%$ of the company's stock must make a tender offer to purchase all of the target's stock. See id. at 16.

281. The Stock Exchange of Thailand requires that listed companies must have at least two independent directors and an approved auditor. See id. at 15 . Indonesia has a two-tier board structure, with a board of commissioners supervising the board of directors. See id. at 13. However, managers have been able to avoid both litigation and important disclosure requirements in ways that one would expect an effective board of directors to have prevented. See id. at 13, 16 (citing disclosure related to derivatives as an especially problematic example).

282. See La Porta, supra note 120, at 1130, 1142-43 (citing shareholder protection scores of 2 for both countries and the lowest legal enforcement scores of any country for Indonesia).

283. Shareholders in Korea are an exception. If they own at least $0.01 \%$ of a publicly traded stock, they can maintain a derivative action. See Scott, supra note 22, at 12 (noting, however, that the derivative action rarely has been used, and that class actions are not expected to be authorized until 2000).

284. Consider, for example, the following increasing debt/equity ratios of several East Asian countries overall, compared to the relatively constant ratios of the United States and Japan: 
erage return on equity ${ }^{285}$ and return on capital employed ${ }^{286}$ for East Asian

\section{Debu/Equity Ratio}

$\begin{array}{llllll}\text { Country } & 1992 & 1993 & 1994 & 1995 & 1996 \\ \text { U.S. } & 106 \% & 102 \% & 97 \% & 94 \% & 90 \% \\ \text { Japan } & 136 \% & 139 \% & 139 \% & 135 \% & 138 \% \\ \text { Indonesia } & 59 \% & 54 \% & 58 \% & 81 \% & 92 \% \\ \text { Malaysia } & 31 \% & 29 \% & 38 \% & 45 \% & 62 \% \\ \text { Thailand } & 71 \% & 81 \% & 103 \% & 135 \% & 155 \% \\ \text { Philippines } & 81 \% & 78 \% & 50 \% & 49 \% & 69 \%\end{array}$

See Michael Pomerleano, The East Asia Crisis and Corporate Finances: The Untold Micro Story, at 7 (1999) (unpublished working paper) (on file with the author).

A few economists have argued that corporate managers in Asia "bet" their companies by borrowing extensively (much in foreign currency) while profits were declining. See Campbell R. Harvey \& Andrew H. Roper, The Asian Bet, Mar. 18, 1999, at 1, 4, 42, in The First ANnual Worid BanK Group-Brookings institution Conference: Financial. Markets and Development: Preventing Crises IN EMERGing Markets, Mar. 26-27, 1999 (on file with the author).

285. The following are the equivalent data for retum on equity; note the relative decline in East Asia compared to the United States and Japan:

\section{Return on Equity (after-tax)}

$\begin{array}{llllll}\text { Country } & 1992 & 1993 & 1994 & 1995 & 1996 \\ \text { U.S. } & 4 \% & 8 \% & 16 \% & 16 \% & 18 \% \\ \text { Japan } & 5 \% & 3 \% & 2 \% & 2 \% & 4 \% \\ \text { Indonesia } & 14 \% & 12 \% & 12 \% & 15 \% & 13 \% \\ \text { Malaysia } & 12 \% & 14 \% & 14 \% & 14 \% & 13 \% \\ \text { Thailand } & 13 \% & 10 \% & 11 \% & 9 \% & 5 \% \\ \text { Philippines } & 4 \% & 7 \% & 16 \% & 12 \% & 9 \%\end{array}$

See Pomerleano, supra note 284, at 17.

286. The following are the equivalent data for return on capital employed (RoCE) (defined as operating profit divided by capital employed). Some believe RoCE is a more accurate indicator of corporate profitability, in part because it is not dependent on accounting conventions such as depreci- 
firms was unimpressive. Moreover, borrowing rates for firms were high. ${ }^{287}$ Managers acting in the interests of shareholders would not have been borrowing excessively to fund new projects during this period.

By 1996 firms in East Asia were in an untenable situation, especially in comparison to firms in other countries. According to the data in notes 284-87, firms in the United States could borrow at $8 \%$ and earn $13 \%$, a net return of $5 \%$, likewise, Japanese firms could earn a net return

ation. In any event, note the relative decline in East Asia compared to the United States and Japan:

RoCE (pre-tax)

$\begin{array}{llllll}\text { Couniry } & 1992 & 1993 & 1994 & 1995 & 1996 \\ \text { U.S. } & 9 \% & 9 \% & 11 \% & 12 \% & 13 \% \\ \text { Japan } & 6 \% & 5 \% & 4 \% & 5 \% & 6 \% \\ \text { Indonesia } & 12 \% & 11 \% & 11 \% & 11 \% & 10 \% \\ \text { Malaysia } & 12 \% & 12 \% & 11 \% & 11 \% & 10 \% \\ \text { Thailand } & 9 \% & 7 \% & 7 \% & 7 \% & 5 \% \\ \text { Philippines } & 6 \% & 7 \% & 7 \% & 8 \% & 5 \%\end{array}$

See Pomerleano, supra note 284, at 18.

287. Domestic bank lending rates were much higher in East Asia than in the U.S. or Japan during this period:

\section{Bank Lending Rrates}

$\begin{array}{llllll}\text { Country } & 1992 & 1993 & 1994 & 1995 & 1996 \\ \text { U.S. } & 6 \% & 6 \% & 7 \% & 9 \% & 8 \% \\ \text { Japan } & 6 \% & 4 \% & 4 \% & 3 \% & 3 \% \\ \text { Indonesia } & 24 \% & 21 \% & 18 \% & 19 \% & 19 \% \\ \text { Malaysia } & 9 \% & 9 \% & 8 \% & 8 \% & 9 \% \\ \text { Thailand } & 18 \% & 16 \% & 14 \% & \text { N/A } & \text { N/A } \\ \text { Philippines } & 19 \% & 15 \% & 15 \% & 15 \% & 15 \%\end{array}$

See Pomerleano, supra note 284, at 20. 
of $3 \%$. In contrast, similar net returns in Indonesia, Thailand, and the Philippines were negative through this period, and net returns in Malaysia were only $1 \%$ in 1996 . East Asian firms simply were not adding value, yet they were continuing to borrow for new projects. Asian firms borrowed from numerous sources, using depository receipts ${ }^{288}$ to raise capital from foreign investors throughout the 1990s, and accessing the Eurobond market to incur substantial additional U.S.-dollar denominated debt. ${ }^{289}$ This situation was not sustainable in the long run.

Much of the above data was available 290 to investors in East Asia prior to the crisis, but was simply ignored. ${ }^{291}$ Ironically, investors in these firms were among those generally regarded as the most sophisticated. ${ }^{292}$ Such investors may have understood the available data, but believed they would be the beneficiaries of a bailout in the event of crisis. ${ }^{293}$ In hindsight (which, of course, is always 20/20), for any semi-aware investor in 1996, the East Asian market was an accident waiting to happen.

Given these facts, and applying the analysis in this article, there are several lessons to be drawn from the Asia crisis. First, markets crash. The Asia crisis was a cycle of mania, panic, and crash, first in foreign exchange markets, but later throughout Asia on most securities exchanges. The crisis mattered; economic growth was stifled, lives ruined, and individual wealth destroyed. ${ }^{294}$ Market failure predominated. Inves-

288. The types of depository receipts include both American Depository Receipts (ADRs) and Global Depository Receipts (GDRs). See Hal S. Scott \& Philip A. Wellons, International FiNANCE: TRANSACtions. POLICY, AND Regulation 110-18 (1998). ADRs and GDRs are created when a domestic depository bank holding shares of a foreign corporation issues receipts backed by the performance of the foreign shares. In the United States, the receipts may be sponsored (approved by the foreign issuer) or unsponsored (not approved). There are two levels of sponsored receipts: Level 1 (traded over-the-counter) and Level II (traded on an exchange). Level II sponsored receipts must be registered with the Securities and Exchange Commission and issuers must comply with certain Generally Accepted Accounting Principles (GAAP). See Harvey \& Roper, supra note 284, at 13.

289. See id. at 16 (calculating that leverage ratios increased through 1997 for firms in China, Indonesia, Malaysia, the Philippines, the Republic of Korea, and Thailand).

290. Although macroeconomic data were available, data on individual firms may not have been available during this period. To the extent such data were unavailable, the information asymmetry theory would explain why investors continued to invest.

291. The cognitive error theory offers one explanation for why investors might have ignored this data.

292. See, e.g. Why Risk Is a Four-Letter Word, THE EconomisT, Sept. 26, 1998, at 72 ("The biggest investors in emerging-market debt are hedge funds or proprietary-trading arms of big investment banks that borrow to boost their returns.").

293. The moral hazard theory explains this behavior.

294. Because emerging markets were subject to contagion, Latin American markets also collapsed along with Asian markets in 1997 and 1998. See Emerging-Market Measles, THE ECONOMIST, Aug. 22, 1998, at 56 (describing the "contagious disease" spreading through emerging markets). 
tors, both foreign and domestic, took on excessive risks, in part because they misperceived risks, in part because they believed government or supranational organizations would save them in the event of crisis. Investors also lacked critical information regarding their investments, mostly because of the use of derivatives, although sufficient warning signs should have been obvious.

During this period, law played an inadequate role. Trust in the East Asia markets was quickly shattered when minority shareholders learned the corporate governance regimes were inadequate to protect them. In retrospect, the ineffectiveness of U.S.-style corporate and securities laws should not be surprising given the widespread family ownership and control of firms, and of the enforcement of law.

Market self-regulation, which operated to a great extent because of the dominance of derivatives in East Asia, was inadequate. Capital controls failed to achieve their intended result. The MMF and World Bank acted as lenders of the last resort, but in ways that created additional distortion and increased the amount of moral hazard (and therefore the probability of a future crash).

Law could have done better. A properly functioning financial system requires a much stronger legal and regulatory infrastructure than do regimes for trade or investment. ${ }^{295}$ Recent proposals for regulatory competition, however, probably would not have prevented the crisis. Private parties already have used derivatives and financial innovation to contract around existing regulation, which has created a regime of regulatory competition even without legislation. To the extent private over-thecounter transactions were not disclosed, rules forcing their disclosure (or rules forcing them into a purely private regime with no legal enforcement) might have eliminated some of the incentives to take on excessive risk. Derivatives risks in East Asia were much larger than either investors or regulators realized. The Asia crisis can be thought of as a failure of risk management, because it is in the risk management interest of a country to open its banking system, which Asian countries did not. ${ }^{296}$

In place of the IMF and World Bank, the United States could have made it clear it would provide loans, without conditions, but at higher

295. See Steven Radelet \& Jeffrey Sachs, What Have We Learned, So Far, From the Asian Financial Crisis?, at 12 (1999) (working paper) (on file with the author).

296. It is excessively risky for a government to have all of its banking exposure be to its own banking system. For the same reasons an individual with human capital invested in firm should diversify by purchasing other stocks, countries should diversify by limiting their exposure to their own banking system. The way to limit exposure to your own banking system is to open it to foreigners. 
market rates. Asian central banks could have undertaken measures to support domestic stock exchanges without encouraging additional moral hazard. Asian governments could have resisted the urge to liberalize markets too quickly, before they had developed the regulatory capacity to manage their liberal economy. Given the ease with which financial innovation enables investors to evade regulation, it was a mistake to liberalize first and then regulate later. ${ }^{297}$

Most importantly, emerging markets governments could have taken actions to dilute the ownership of families who controlled large firms, and thereby (eventually) could have improved enforcement of corporate governance rules. These actions still have not been taken. So long as this ownership structure persists, the classes of market failure associated with crashes will persist, and it will only be a matter of time before history repeats itself.

\section{CONCLUSION}

By the time you are reading this article, it is likely that another financial market has crashed. Did U.S. technology stocks lead the descent into the abyss? Or was it Latin America, again? Could we have foreseen or prevented the crash?

The message of this article is twofold. First, market crashes are important and are due to various market failures, including investor cognitive error, moral hazard, and information asymmetry. Second, law can do something about crashes, in addition to minimizing agency and information costs. Unfortunately, existing legal rules exacerbate the market failures that lead to crashes and fail to create the trust necessary to support healthy financial markets. Legal reform-in particular, creating regulatory competition in public lending and diluting family ownership of large firms-can help to prevent future crashes.

297. This lesson has been leamed before. When financial markets in the United States and other industrialized countries were less developed-in the 19th and early 20th centuries-they suffered a series of financial crises and panics similar to the Asia crisis. See Radelet \& Sachs, supra note 295 , at 13. 
